\title{
Functions of transmembrane domain 3 of human melanocortin-4 receptor
}

\author{
Xiu-Lei Mo, Rui Yang and Ya-Xiong Tao \\ Department of Anatomy, Physiology and Pharmacology, College of Veterinary Medicine, Auburn University, 212 Greene Hall, Auburn, Alabama 36849, USA \\ (Correspondence should be addressed to Y-X Tao; Email: taoyaxi@auburn.edu)
}

\begin{abstract}
The melanocortin-4 receptor (MC4R) is a G protein-coupled receptor critical for maintaining energy homeostasis. Transmembrane domain 3 (TM3) of MC4R contains residues that were suggested to be essential in ligand binding and signaling. Several MC4R mutations in TM3 are associated with human obesity. To gain a better understanding of the functions of TM3, we analyzed the functions of 26 residues in TM3 using alanine-scanning mutagenesis. We showed that all mutants had normal cell-surface expression. Four mutants were defective in ligand binding and signaling and six mutants had normal ligand binding but impaired cAMP production. L140A had increased basal cAMP level. To further characterize the function of L140, we generated 17 additional L140 mutants. Fifteen L140 mutants had significantly decreased cell-surface expression, with L140R and L140V expressed normally. Ten L140 mutants had increased basal cAMP activities. Four L140 mutants were defective in ligand-stimulated cAMP generation. Interestingly, with the ERK1/2 pathway, we showed that nine constitutively active mutants had similar levels of basal pERK1/2 as that of WT, and two signaling defective mutants had similar levels of pERK1/2 as that of WT upon agonist stimulation, different from their CAMP signaling properties, suggesting biased signaling in these mutant receptors. In summary, we identified 13 residues in TM3 that were essential for ligand binding and/or signaling. Moreover, L140 was critical for locking MC4R in inactive conformation and several mutants showed biased signaling in CAMP and ERK1/2 signaling pathways.
\end{abstract}

Journal of Molecular Endocrinology (2012) 49, 221-235

\section{Introduction}

Obesity is rapidly becoming a critical health problem in the USA, with nearly $70 \%$ of adults considered as overweight or obese compared with $<25 \% 40$ years ago (Flegal et al. 2012). Obesity and associated comorbidities, such as type II diabetes mellitus, hypertension, and heart diseases, have reached epidemic proportions in the USA and in other developed countries (Bhargava et al. 2004).

Studies have demonstrated that the melanocortin- 4 receptor (MC4R) is critical for regulating food intake and energy expenditure in mice (Huszar et al. 1997). $M c 4 r$ knockout mice have maturity-onset obesity, hyperphagia, hyperglycemia, and hyperinsulinemia. Human genetic studies have demonstrated that mutations in $M C 4 R$ are the most common cause of monogenic obesity, characterized by its early onset and severity (Farooqi et al. 2003). More than $150 \mathrm{MC} 4 R$ mutations, including nonsense, missense, frameshift, and inframe deletions, have been identified from obese patient cohorts of different ethnic origins (Tao 2005, 2010).

The MC4R is a member of family A G proteincoupled receptors (GPCRs) with seven transmembrane (TM) helices connected by alternating extracellular and intracellular loops. Since the cloning of the MC4R by Gantz et al. (1993), it has been established that this receptor subtype primarily couples to the stimulatory $\mathrm{G}$ protein $\left(\mathrm{G}_{\mathrm{s}}\right)$, which increases adenylyl cyclase activity and subsequently leads to increased cAMP production that then enhances the activity of protein kinase A (PKA). The activation of MC4R by the endogenous agonist, $\alpha$-melanocyte-stimulating hormone ( $\alpha$-MSH), results in decreased food intake and increased energy expenditure, while the inhibition of MC4R by the endogenous antagonist, agouti-related protein, leads to increased food intake and decreased energy expenditure (Fan et al. 1997, Fong et al. 1997, Ollmann et al. 1997). Ligands targeting the MC4R have significant therapeutic potential in obesity treatment. Therefore, a better understanding of MC4R function at the molecular level is critical for the development of effective therapy for human obesity.

In addition to the conventional $\mathrm{G}_{\mathrm{s}}-\mathrm{cAMP}-\mathrm{PKA}$ pathway, it has been recently demonstrated that MC4R also activates ERK1/2 (Daniels et al. 2003, Vongs et al. 2004) and this signaling pathway is involved in melanocortin-induced decreases in food intake (Sutton et al. 2005). Thus, activation of the ERK1/2 pathway is one cellular mechanism that may underlie the regulation of energy homeostasis mediated by the MC4R. 
TM domain 3 (TM3) has been suggested to be important for ligand binding and activation in various GPCRs (Farrens et al. 1996, Sheikh et al. 1996, Gether et al. 1997, Lu \& Hulme 1999, Rasmussen et al. 1999, Tao et al. 2000, Ballesteros et al. 2001, Roth et al. 2008). Studies based on site-directed mutagenesis (Rasmussen et al. 1999, Tao et al. 2000, Ballesteros et al. 2001, Roth et al. 2008), electron paramagnetic resonance spectroscopy (Farrens et al. 1996), fluorescence spectroscopy (Gether et al. 1997), and engineered metal ion-binding site studies (Sheikh et al. 1996) have indicated the potential role of TM3 in GPCR functions. Indeed, direct evidence from high-resolution crystal structures of several GPCRs, such as rhodopsin (Palczewski et al. 2000), $\beta_{2}$-adrenoceptor (Cherezov et al. 2007, Rasmussen et al. 2007, 2011, Rosenbaum et al. 2007, 2011), and human A (2A) adenosine receptor (Jaakola et al. 2008), further confirmed that the movement of TM3 was critical for the conversion of the receptor to the active conformation.

A few recent studies suggested that TM3 of MC4R was important for ligand binding and activation (Yang et al. 2000, Haskell-Luevano et al. 2001, Lagerstrom et al. 2003, Pogozheva et al. 2005, Chen et al. 2007). Some residues in TM3 have been suggested to be essential in forming binding pockets that directly interact with ligand (Yang et al. 2000), and some residues in TM3 have been implicated to be crucial in receptor activation by participating in a conformational switch upon ligand stimulation (Chen et al. 2007). In particular, several naturally occurring $M C 4 R$ mutations found in TM3 have been associated with human obesity (Tao 2009, 2010). However, the structure-function relationship of MC4R TM3 has not been fully elucidated. In the current study, pharmacological characterization of 26 amino acid residues (Fig. 1, from V119 to V145, excluding S136 and DRYFTI motif) was performed systematically to gain further insight into the molecular basis involved in cell-surface expression, ligand binding, and receptor activation.

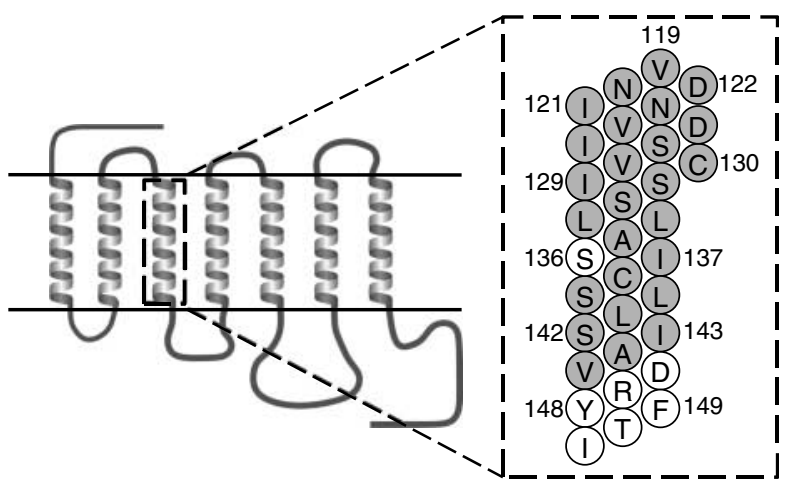

Figure 1 Schematic model of the hMC4R with the mutations characterized in this study highlighted with gray background.

\section{Materials and methods}

\section{Hormones and supplies}

$\left[\mathrm{Nle}^{4}, \mathrm{D}-\mathrm{Phe} \mathrm{e}^{7}\right]-\boldsymbol{\alpha}-\mathrm{MSH}$ (NDP-MSH) was purchased from Peptides International (Louisville, KY, USA). $\left[{ }^{125} \mathrm{I}\right]-\mathrm{NDP}-\mathrm{MSH}$ was prepared using a modified chloramine-T method as described previously (Xiang et al. 2006). Cell culture plates and flasks were purchased from Corning (Corning, NY, USA). Cell culture media, newborn calf serum, antibiotics, and reagents were obtained from Invitrogen.

\section{In vitro mutagenesis of MC4R}

WT human (h) MC4R was generously provided by Dr Ira Gantz (University of Michigan, Ann Arbor, MI, USA) and tagged with c-myc epitope tag at the $\mathrm{N}$-terminus as described previously (Tao \& Segaloff 2003). Mutations were generated using QuikChange site-directed mutagenesis kit (Stratagene, La Jolla, CA, USA) with WT myc-hMC4R as template (Tao \& Segaloff 2003). Plasmids used for transfection were prepared using IsoPure Maxi Prep Kit (Denville Scientific, Metuchen, NJ, USA). Automated DNA sequencing was performed (University of Chicago Cancer Research Center DNA Sequencing Facility, Chicago, IL, USA) to confirm that the intended mutations were introduced in the constructs correctly.

\section{Cell culture and DNA transfection}

HEK293T cells were obtained from American Type Culture Collection (Manassas, VA, USA) and maintained at $5 \% \mathrm{CO}_{2}$ in DMEM containing $10 \mathrm{mM}$ HEPES, $10 \%$ newborn calf serum, 100 units $/ \mathrm{ml}$ penicillin, $100 \mu \mathrm{g} / \mathrm{ml}$ streptomycin, $0 \cdot 25 \mu \mathrm{g} / \mathrm{ml}$ amphotericin B, and $100 \mu \mathrm{g} / \mathrm{ml}$ gentamicin. Cells were plated on gelatin-coated $35 \mathrm{~mm}$ six-well clusters and transfected at $50-70 \%$ confluency using calcium phosphate transfection method (Chen \& Okayama 1987). Ligand binding assay, cAMP signaling assay, and flow cytometry assays were performed $48 \mathrm{~h}$ after transfection.

\section{Radioligand binding assay}

Ligand binding assays were performed as described in detail previously (Tao \& Segaloff 2003). Briefly, $48 \mathrm{~h}$ after transfection, cells were washed twice with warm Waymouth/BSA and then incubated with 100000 c.p.m. of ${ }^{125}$ I-NDP-MSH with or without different concentrations of unlabeled NDP-MSH (from $10^{-11}$ to $10^{-6} \mathrm{M}$ ) at $37^{\circ} \mathrm{C}$ for $1 \mathrm{~h}$. Cells were then washed twice with cold Hank's balanced salt solution containing $1 \mathrm{mg} / \mathrm{ml} \mathrm{BSA}$ and subsequently solubilized with $100 \mu \mathrm{l}$ of $0.5 \mathrm{M} \mathrm{NaOH}$. Cell lysates were 
then collected using cotton swabs and counted using a gamma counter. All determinations were performed in duplicate. Apparent maximal binding ( $B_{\max }$; Tansky et al. 2007) or receptor occupancy (Wang et al. 2008) and concentrations that result in $50 \%$ inhibition $\left(\mathrm{IC}_{50}\right)$ were calculated using Prism 4.0 Software (San Diego, CA, USA).

\section{cAMP signaling assay}

Forty-eight hours after transfection, cells were washed twice with warm Waymouth/BSA and then incubated in fresh Waymouth/BSA containing $0.5 \mathrm{mM}$ isobutylmethylxanthine (Sigma-Aldrich) at $37^{\circ} \mathrm{C}$ for $15 \mathrm{~min}$. Subsequently, either buffer alone or different concentrations of NDP-MSH (from $10^{-12}$ to $10^{-6} \mathrm{M}$ ) were added and the incubation was continued for another hour. Cells were then solubilized with cold $0.5 \mathrm{~N}$ perchloric acid containing $180 \mu \mathrm{g} / \mathrm{ml}$ theophylline (phosphodiesterase inhibitor). The supernatant was collected to measure the level of cAMP production using RIA (Fan et al. 2008). All determinations were performed in triplicate. Maximal response $\left(R_{\max }\right)$ and concentrations that result in $50 \%$ maximal response $\left(\mathrm{EC}_{50}\right)$ were calculated using Prism 4.0 Software.

\section{Flow cytometry assay}

The cell surface and total expression level of WT and mutant MC4Rs were quantified using flow cytometry technique as described earlier (Fan \& Tao 2009) except that transiently transfected cells were used. Briefly, $48 \mathrm{~h}$ after transfection, cells were placed on ice and washed twice with filtered PBS for immunohistochemistry (PBS-IH, $137 \mathrm{mM} \mathrm{NaCl}, 2.7 \mathrm{mM} \mathrm{KCl}$, $1.4 \mathrm{mM} \mathrm{KH} \mathrm{PO}_{4}$, and $4.3 \mathrm{mM} \mathrm{Na} \mathrm{NPO}_{4}, \mathrm{pH} 7 \cdot 4$ ), fixed with $4 \%$ paraformaldehyde for $30 \mathrm{~min}$, permeabilized (only for measurement of total expression level) with $1 \%$ Triton X-100 in PBS-IH for $4 \mathrm{~min}$, and then incubated with blocking solution (PBS-IH with $5 \% \mathrm{BSA}$ ) for $1 \mathrm{~h}$. Cells were then incubated with monoclonal anti-myc (9E10) antibody (Developmental Studies Hybridoma Bank at the University of Iowa, Iowa City, IA, USA) diluted 1:100 in PBS-IH with $0 \cdot 1 \%$ BSA for $1 \mathrm{~h}$. Cells were then washed thoroughly and incubated for another hour with Alexa Fluor 488conjugated goat anti-mouse IgG (Invitrogen) diluted 1:1000 in PBS-IH with $0 \cdot 1 \%$ BSA. Cells were then washed three times with PBS-IH and fluorescence signals were collected with C6 Accuri Cytometer (Accuri Cytometers, Inc., Ann Arbor, MI, USA). Fluorescence from cells transfected with empty vector was used as negative control. The expression level of the mutants was calculated as a percentage of WT MC4R expression using the formula: (mutant fluorescence-pcDNA3 fluorescence)/(WT fluorescence-pcDNA3 fluorescence) $\times 100 \%$ (Wang et al. 2008). For assessing the effect of proteasome or lysosome inhibitor on total receptor expression, $24 \mathrm{~h}$ after transfection, cells were treated with MG132 $(25 \mu \mathrm{M}), \mathrm{NH}_{4} \mathrm{Cl}(25 \mathrm{mM})$, or chloroquine $(100 \mu \mathrm{M})$ for $18 \mathrm{~h}$ before the measurement.

\section{ERK1/2 signaling assay}

For studying ERK1/2 signaling, cells were washed twice and incubated with Waymouth/BSA (Waymouth's MB752/1 media (Sigma-Aldrich) containing $1 \mathrm{mg} / \mathrm{ml} \mathrm{BSA)} 24 \mathrm{~h}$ after transfection and starved for $18 \mathrm{~h}$ at $37^{\circ} \mathrm{C}$ before hormone stimulation. Cells were treated for $5 \mathrm{~min}$ with either buffer alone or $1 \mu \mathrm{M}$ NDP-MSH, solubilized in lysis buffer (20 mM Hepes, $\mathrm{pH} 7 \cdot 4,150 \mathrm{mM} \mathrm{NaCl}$, $0.5 \%$ NP-40, 2 mM EDTA, $1 \mathrm{mM}$ sodium orthovanadate, and $1 \mathrm{mM}$ sodium fluoride), and then clarified by centrifugation at $4{ }^{\circ} \mathrm{C}, 14000 \mathrm{~g}$ for $15 \mathrm{~min}$. Thirty micrograms of supernatant proteins were separated on $10 \%$ SDS-PAGE gel and then transferred to PVDF membrane. Phosphorylated ERK1/2 and $\beta$-tubulin were detected by immunoblotting with rabbit antipERK1/2 antibody (1:1000 1:3000, Cell Signaling Technology, Beverly, MA, USA) and mouse anti$\beta$-tubulin antibody (1:5000 1:20 000, Developmental Studies Hybridoma Bank at the University of Iowa) respectively. Membranes were then washed thoroughly with Tris-buffered saline (TBS, $20 \mathrm{mM}$ Tris, $0.5 \mathrm{M} \mathrm{NaCl}$, $\mathrm{pH} 7 \cdot 5$ ) containing $0 \cdot 1 \%$ Tween 20 (TBST) and then probed with HRP-conjugated secondary donkey anti-rabbit (1:500 1:2000, Jackson ImmunoResearch Laboratories, West Grove, PA, USA) and HRP-conjugated donkey anti-mouse (1:5000 1:20 000, Jackson ImmunoResearch Laboratories) at room temperature for $2 \mathrm{~h}$. The membranes were then washed with TBST and a final wash with TBS. Blots were then visualized using enhanced chemiluminescence reagent (Pierce, Rockford, IL, USA) and quantified using Image J 1.44 Software (National Institute of Health, Bethesda, MD, USA) after densitometric scanning of the films. ERK1/2 phosphorylation was normalized according to the loading of proteins by expressing the data as a ratio of pERK1/2 over $\beta$-tubulin. The phosphorylated ERK1/2 was expressed as a percent of the basal value of WT hMC4R.

\section{Statistical analyses}

The significance of differences in cell-surface expression level, signaling and binding parameters, and pERK1/2 activities, between the WT and mutant hMC4Rs, were analyzed using Student's $t$-test with Prism 4.0 Software. 


\section{Results}

\section{Expression, ligand binding, and signaling properties of the TM3 mutant hMC4Rs}

To study the importance of TM3 residues in ligand binding and signaling, we mutated 26 TM3 residues as shown in Fig. 1, excluding previously well-studied S136 (Fan \& Tao 2009) and DRYFTI motifs (Tao \& Segaloff 2004, Yamano et al. 2004, Govaerts et al. 2005), by alanine-scanning mutagenesis. For these studies, TM3 residues were mutated to Ala (or substitution of Ala by Gly) to eliminate the side chain interactions. Results obtained from these mutants would reveal which amino acid residues are important for ligand binding and/or receptor activation. A total of 26 TM3 mutants were generated.

To quantitate the cell-surface and total receptor expression levels of mutant MC4Rs, flow cytometry technique was used as described in the Materials and methods section. The results demonstrated that all TM3 mutants were expressed normally on the cell surface with no significant difference compared with WT MC4R (Fig. 2A). One mutant, I129A, had a small,
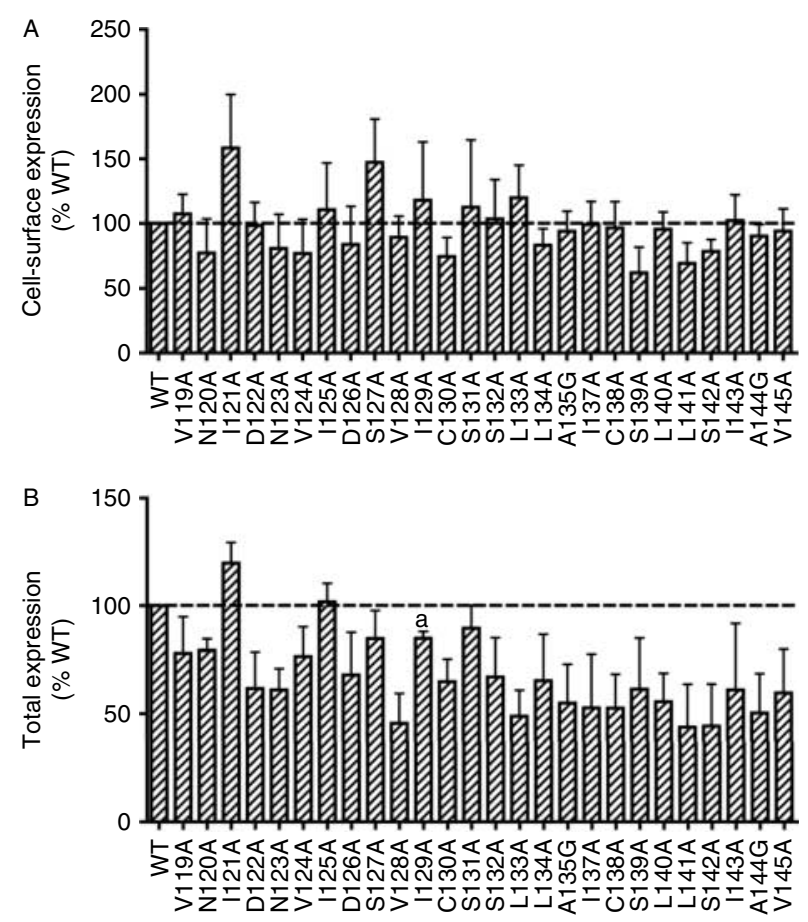

Figure 2 Cell-surface expression (A) and total expression (B) of WT and TM3 mutant hMC4Rs measured by flow cytometry. The results are expressed as percentage of cell-surface or total expression levels of the WT hMC4R after correction of the nonspecific staining in cells transiently transfected with the empty vector as described in the Materials and methods section. Data were mean \pm S.E.M. of three experiments. The statistical significance is indicated as follows: a significantly different from WT hMC4R, $P<0.05$. although statistically significant, decrease in total expression, and the other 25 mutants had normal total expression levels (Fig. 2B).

Ligand binding and signaling properties of these mutants were assessed using NDP-MSH. Because NDPMSH is a superpotent analog of $\alpha$-MSH (Sawyer et al. 1980), we reasoned that if a mutant cannot bind and respond to NDP-MSH, it would not be able to bind and respond to the endogenous ligands such as $\alpha$ - or $\beta$-MSH.

As shown in Fig. 3 and Table 1, the WT hMC4R binds to NDP-MSH with an $\mathrm{IC}_{50}$ of $108 \cdot 83 \pm 22 \cdot 60 \mathrm{nM}$. Of the 26 mutants, D126A had no measurable binding. Six mutants, D122A, I125A, L133A, L134A, S139A, and L140A, had decreased maximal binding. Four mutants, V124A, I125A, L140A, and I143A, had lower $\mathrm{IC}_{50} \mathrm{~s}$ (increased affinities). Upon NDP-MSH stimulation, WT MC4R responded with increases in cAMP accumulation in a dose-dependent manner with an $\mathrm{EC}_{50}$ of $0.51 \pm 0.07 \mathrm{nM}$ (Fig. 4 and Table 1). D126A had no response to NDP-MSH stimulation, consistent with its lack of detectable binding. Three mutants, D122A, L133A, and L140A, had decreased maximal response and/or increased $\mathrm{EC}_{50} \mathrm{~s}$, consistent with their decreased ligand binding. Five mutants, S127A, V128A, S132A, L141A, and I143A, despite normal ligand binding, had decreased maximal response and/or increased $\mathrm{EC}_{50} \mathrm{~s}$, suggesting that these mutants were partially defective in signaling. The other mutants could signal at least as well as WT MC4R in terms of maximal signaling. Three mutants, S142A, A144G, and V145A, even had significantly increased maximal response. Several mutants, including N120A, S139A, L140A, and L141A, had decreased $\mathrm{EC}_{50} \mathrm{~s}$ (Fig. 4 and Table 1).

As it was suggested that basal signaling might be important for maintaining energy homeostasis in humans (Srinivasan et al. 2004), we also measured the basal signaling of the mutant MC4Rs. As shown in Fig. 5, two mutants, I137A and L140A, had significantly increased basal signaling. Of the remaining 24 mutants, seven had decreased basal signaling and the other mutants had normal levels of basal signaling.

\section{Expression, ligand binding, and signaling properties of the L140 mutant hMC4Rs}

As L140 ${ }^{3}{ }^{43}$ (superscript indicates BallesterosWeinstein numbering for GPCR residues; Ballesteros \& Weinstein (1995)), a highly conserved residue presenting in $74 \%$ family A GPCRs (Mirzadegan et al. 2003), has been suggested to be important in stabilizing the inactive conformation of GPCRs (Latronico et al. 1998, Baranski et al. 1999, Lu \& Hulme 1999, Kosugi et al. 2000, Tao et al. 2000; reviewed in Tao (2008)), saturation mutagenesis was performed at this 

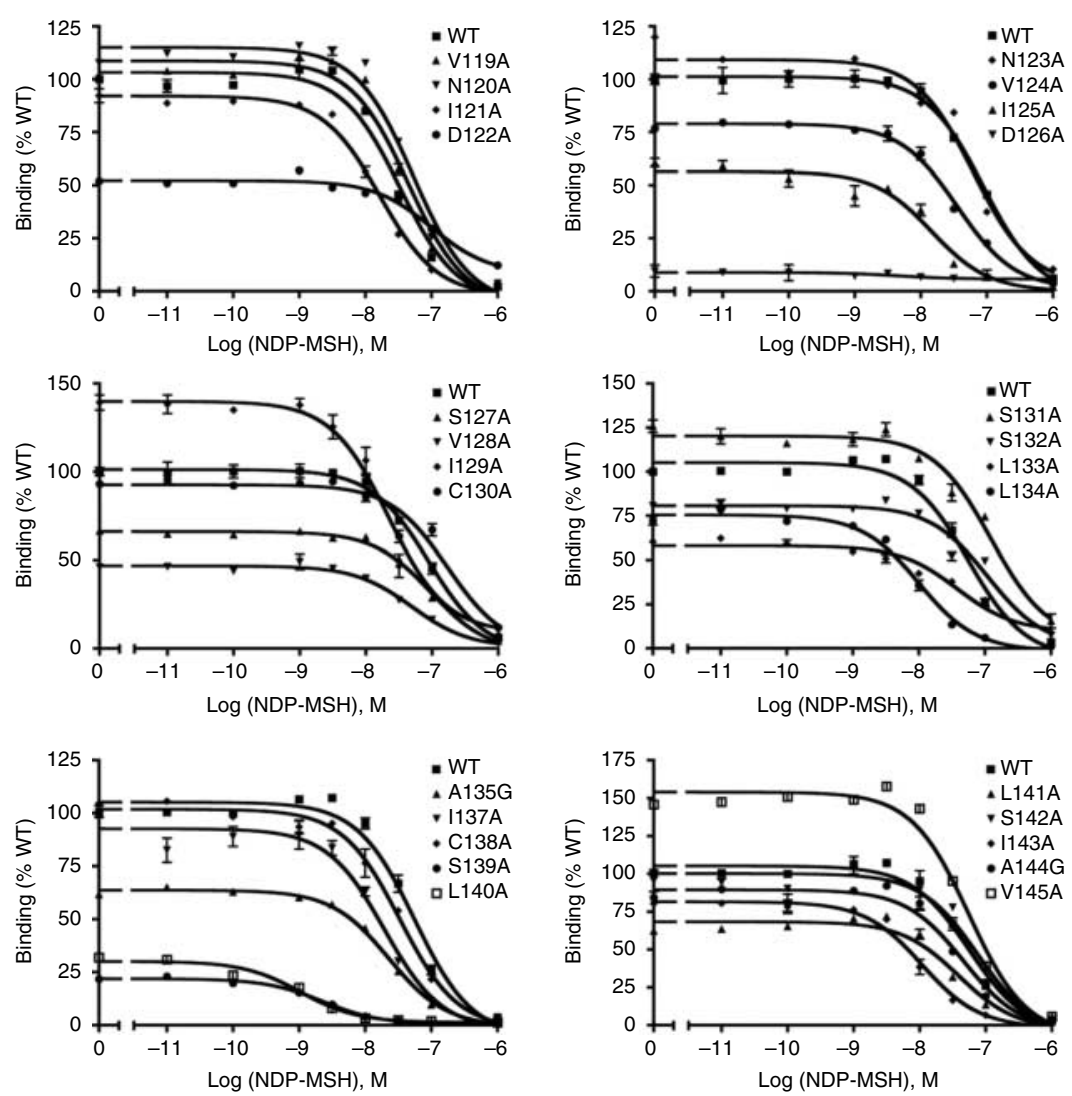

Figure 3 Ligand binding properties of the WT and mutant hMC4Rs with NDP-MSH as the ligand. The binding of ${ }^{125} \mathrm{I}-\mathrm{NDP}-\mathrm{MSH}$ to $\mathrm{hMC} 4 \mathrm{R}$ on intact cells was measured as described in the Materials and methods section. Results shown are expressed as percentage of WT binding \pm range from duplicate determinations within one experiment. All experiments were performed three to five times.

loci to gain further detailed information on the structure-function relationship of L140 in MC4R.

Seventeen additional L140 mutants were generated (excluding $\mathrm{L} 140 \mathrm{H}$, which we failed to generate after several attempts), and their cell-surface and total receptor expression were studied (Fig. 6). Two mutants, L140G and L140V, had both normal cell-surface and total receptor expression. Three mutants, L140C, L140I, and L140K, had significantly decreased cellsurface expression with normal total expression, suggesting that these mutants were intracellularly retained. Ten L140 mutants, including mutations of L140 to D, E, F, M, N, Q, S, T, W, and Y, had significantly decreased cell-surface expression, most likely due to their significantly decreased total expression. Two mutants, L140P and L140R, had normal cell-surface expression (Fig. 6A), but with decreased total expression (Fig. 6B). In order to study whether the decreased total receptor expression was due to accelerated protein degradation, total expression of these ten L140 mutants was measured with or without the treatment of proteasome inhibitor (25 $\mu \mathrm{M}$ MG132) or lysosome inhibitors $\left(25 \mathrm{mM} \mathrm{NH}_{4} \mathrm{Cl}\right.$ or $100 \mu \mathrm{M}$ chloroquine) as described in the Materials and methods section. As shown in Fig. 7, there was no significant increase in total expression of the mutant and WT hMC4R upon the treatment of proteasome or lysosome inhibitors.

The ligand binding property of the 17 L140 mutants was also studied. As shown in Fig. 8 and Table 2, L140G and L140V, although with normal cell-surface expression, had significantly decreased maximal binding. Twelve mutants, mutations of L140 to C, D, E, F, I, $\mathrm{M}, \mathrm{N}, \mathrm{Q}, \mathrm{S}, \mathrm{T}, \mathrm{W}$, and $\mathrm{Y}$, had decreased maximal binding (Fig. 8 and Table 2), most likely due to their largely decreased cell-surface expression (Fig. 6A). Three mutants, mutations of L140 to K, P, and R, had normal ligand binding.

The signaling properties of the 17 L140 mutants are presented in Fig. 9 and Table 2. Upon NDP-MSH stimulation, ten mutants, mutations of L140 to C, D, F, I, M, N, Q, S, T, and Y, had decreased maximal response and/or increased $\mathrm{EC}_{50} \mathrm{~s}$, which were consistent with their decreased cell-surface expression levels. Mutant 
Table 1 Ligand binding and NDP-MSH-stimulated signaling of WT and mutant hMC4Rs. The data were expressed as the mean \pm S.E.M. of three to five independent experiments for the mutant hMC4Rs. The maximal responses $\left(R_{\max }\right)$ were $2509 \cdot 55 \pm 160 \cdot 14$ pmol cAMP $/ 10^{6}$ cells for WT hMC4R

\begin{tabular}{|c|c|c|c|c|c|}
\hline \multirow[b]{2}{*}{ hMC4R } & \multirow[b]{2}{*}{$n$} & \multicolumn{2}{|c|}{ NDP-MSH binding } & \multicolumn{2}{|c|}{ NDP-MSH-stimulated cAMP } \\
\hline & & $\mathrm{IC}_{50}(\mathrm{nM})$ & $B_{\max }(\% \mathrm{WT})$ & $\mathrm{EC}_{50}(\mathrm{nM})$ & $R_{\max }(\% \mathrm{WT})$ \\
\hline WT & 29 & $108 \cdot 83 \pm 22 \cdot 60$ & 100 & $0.51 \pm 0.07$ & 100 \\
\hline V119A & 5 & $56.71 \pm 6.08$ & $104 \cdot 21 \pm 24 \cdot 30$ & $0.30 \pm 0.11$ & $115 \cdot 88 \pm 18 \cdot 10$ \\
\hline N120A & 5 & $46 \cdot 01 \pm 17 \cdot 89$ & $86 \cdot 16 \pm 27 \cdot 89$ & $0.39 \pm 0.03^{a}$ & $118.02 \pm 22.03$ \\
\hline I121A & 5 & $26 \cdot 08 \pm 5 \cdot 94$ & $81 \cdot 73 \pm 13.73$ & $0.12 \pm 0.01$ & $104 \cdot 73 \pm 10 \cdot 26$ \\
\hline D122A & 5 & $50 \cdot 78 \pm 26 \cdot 24$ & $55 \cdot 83 \pm 13 \cdot 71^{\mathrm{b}}$ & $0.68 \pm 0.12^{b}$ & $87 \cdot 76 \pm 25 \cdot 20$ \\
\hline N123A & 5 & $48 \cdot 42 \pm 8 \cdot 75$ & $77 \cdot 29 \pm 11 \cdot 53$ & $0.19 \pm 0.04$ & $79 \cdot 79 \pm 20 \cdot 53$ \\
\hline V124A & 4 & $33.90 \pm 10 \cdot 33^{b}$ & $119 \cdot 56 \pm 35.00$ & $0.18 \pm 0.07$ & $99 \cdot 58 \pm 19 \cdot 14$ \\
\hline I125A & 4 & $18 \cdot 43 \pm 10 \cdot 17^{a}$ & $42 \cdot 78 \pm 19 \cdot 04^{c}$ & $0.28 \pm 0.04$ & $74 \cdot 83 \pm 32 \cdot 50$ \\
\hline D126A & 4 & $N^{c}$ & $N^{c}$ & $N D^{c}$ & $\mathrm{ND}^{\mathrm{c}}$ \\
\hline S127A & 4 & $68 \cdot 53 \pm 33 \cdot 61$ & $71 \cdot 11 \pm 12 \cdot 12$ & $0.63 \pm 0.38$ & $64 \cdot 10 \pm 7 \cdot 79^{a}$ \\
\hline V128A & 4 & $51.08 \pm 25.94$ & $46.42 \pm 19.98$ & $4 \cdot 71 \pm 2 \cdot 02$ & $55 \cdot 99 \pm 17 \cdot 84^{b}$ \\
\hline I129A & 4 & $24 \cdot 09 \pm 5 \cdot 43$ & $116 \cdot 79 \pm 24 \cdot 01$ & $0.63 \pm 0.26$ & $86 \cdot 12 \pm 23.93$ \\
\hline C130A & 4 & $100 \cdot 09 \pm 36.06$ & $82 \cdot 81 \pm 19 \cdot 51$ & $0.68 \pm 0.31$ & $88.09 \pm 10.64$ \\
\hline S131A & 4 & $78 \cdot 71 \pm 22 \cdot 06$ & $108 \cdot 99 \pm 32 \cdot 19$ & $0.42 \pm 0.33$ & $74 \cdot 71 \pm 15 \cdot 97$ \\
\hline S132A & 4 & $70 \cdot 13 \pm 22 \cdot 33$ & $75.89 \pm 3.78$ & $0.64 \pm 0.22$ & $66 \cdot 46+13 \cdot 24^{\mathrm{b}}$ \\
\hline L133A & 4 & $43.92 \pm 15.01$ & $61 \cdot 77 \pm 4.02^{d}$ & $0.74 \pm 0.35$ & $41 \cdot 46 \pm 13 \cdot 88^{\mathrm{a}}$ \\
\hline L134A & 3 & $38 \cdot 43 \pm 14 \cdot 27$ & $80 \cdot 15 \pm 5 \cdot 98^{b}$ & $0.71 \pm 0.18$ & $105 \cdot 16 \pm 15 \cdot 57$ \\
\hline A135G & 3 & $125 \cdot 60 \pm 55 \cdot 60$ & $81 \cdot 74 \pm 9 \cdot 94$ & $0.89 \pm 0.07$ & $91 \cdot 08 \pm 13 \cdot 80$ \\
\hline I137A & 3 & $75 \cdot 85 \pm 28 \cdot 20$ & $99 \cdot 74 \pm 5 \cdot 46$ & $0.67 \pm 0.28$ & $84 \cdot 14 \pm 10 \cdot 06$ \\
\hline C138A & 3 & $126 \cdot 78 \pm 48 \cdot 30$ & $91 \cdot 40 \pm 14.92$ & $0.56 \pm 0.07$ & $85.40 \pm 15.06$ \\
\hline S139A & 3 & $9.59 \pm 3.69$ & $36 \cdot 66 \pm 7 \cdot 87^{a}$ & $0.26 \pm 0.07^{a}$ & $90 \cdot 66 \pm 17.02$ \\
\hline L140A & 4 & $3 \cdot 12 \pm 0 \cdot 70^{\mathrm{a}}$ & $33 \cdot 35 \pm 2.36^{d}$ & $0.01 \pm 0.01^{a}$ & $29 \cdot 96 \pm 2 \cdot 71^{d}$ \\
\hline L141A & 4 & $100 \cdot 58 \pm 23 \cdot 25$ & $95 \cdot 47 \pm 10 \cdot 38$ & $0.13 \pm 0.01^{a}$ & $77 \cdot 93 \pm 8.63^{\mathrm{b}}$ \\
\hline S142A & 4 & $338 \cdot 76 \pm 137 \cdot 72$ & $103 \cdot 38 \pm 7 \cdot 49$ & $0.64 \pm 0.06$ & $130 \cdot 60 \pm 8 \cdot 46^{a}$ \\
\hline I143A & 4 & $35.83 \pm 8.34^{b}$ & $103 \cdot 83 \pm 9.26$ & $3.91 \pm 0.24^{d}$ & $22 \cdot 20 \pm 3 \cdot 35^{d}$ \\
\hline A144G & 4 & $136 \cdot 53 \pm 32 \cdot 68$ & $105.06 \pm 6 \cdot 81$ & $1.30 \pm 0.09^{d}$ & $178.09 \pm 13.46^{a}$ \\
\hline V145A & 4 & $194 \cdot 46 \pm 52 \cdot 91$ & $135 \cdot 63 \pm 11 \cdot 70^{c}$ & $1 \cdot 50 \pm 0.11^{d}$ & $223.55 \pm 29 \cdot 43^{\mathrm{a}}$ \\
\hline
\end{tabular}

aSignificantly different from corresponding WT receptor, $P<0.01$.

${ }^{\mathrm{b}}$ Significantly different from corresponding WT receptor, $P<0.05$.

${ }^{\mathrm{N} D}$, could not be detected.

${ }^{\mathrm{d}}$ Significantly different from corresponding WT receptor, $P<0 \cdot 001$.

L140G, expressed normally on the cell-surface, was impaired in signaling in terms of maximal response, most likely due to its defect in ligand binding. Mutant L140R also had significantly decreased maximal response, although it had normal cell-surface expression and ligand binding. Other mutants could signal at least as well as WT MC4R in terms of maximal signaling. L140V had decreased $\mathrm{EC}_{50}$ s (Fig. 9 and Table 2).

We also measured the basal signaling of the L140 mutants (Table 2). Ten mutants, mutations of L140 to C, D, E, K, N, P, Q, S, T, and V, had increased basal cAMP activity. Four mutants, mutations of L140 to I, M, R, and $\mathrm{Y}$, had decreased basal cAMP production, and the other mutants had normal basal signaling activities.

\section{Signaling properties of L140 mutants at the ERK1/2 pathway}

Because the MC4R can signal through both cAMP and ERK1/2 and because the ERK1/2 signaling pathway has been suggested to be one cellular mechanism underlying the regulation of energy homeostasis by MC4R (Sutton et al. 2005), we asked whether there is biased signaling at the MC4R. The L140 mutants studied herein (Fig. 9) revealed four signaling defective mutants (SDMs, including mutations of L140 to G, I, M, and R) and nine constitutively active mutants (CAMs, including mutations of L140 to C, E, K, N, P, Q, S, T, and V) in the cAMP pathway. These mutants are excellent tools to address two questions: 1) are mutants constitutively active in the cAMP pathway also constitutively active in the ERK1/2 pathway? and 2) are mutants defective in ligand-induced signaling in the cAMP pathway also defective in responding to ligand stimulation in the ERK1/2 pathway? Therefore, the ability of these L140 mutants to activate ERK1/2 was studied either in the basal condition (for the CAMs) or in maximal ligandstimulated condition (for the SDMs). A time-course experiment was performed to determine the optimal time for ERK1 / 2 activation in WT MC4R, and the level of pERK1 $/ 2$ reached maximum in 5 min (data not shown). In these experiments, the WT or mutant MC4R were transfected into HEK293T cells and subsequently treated 

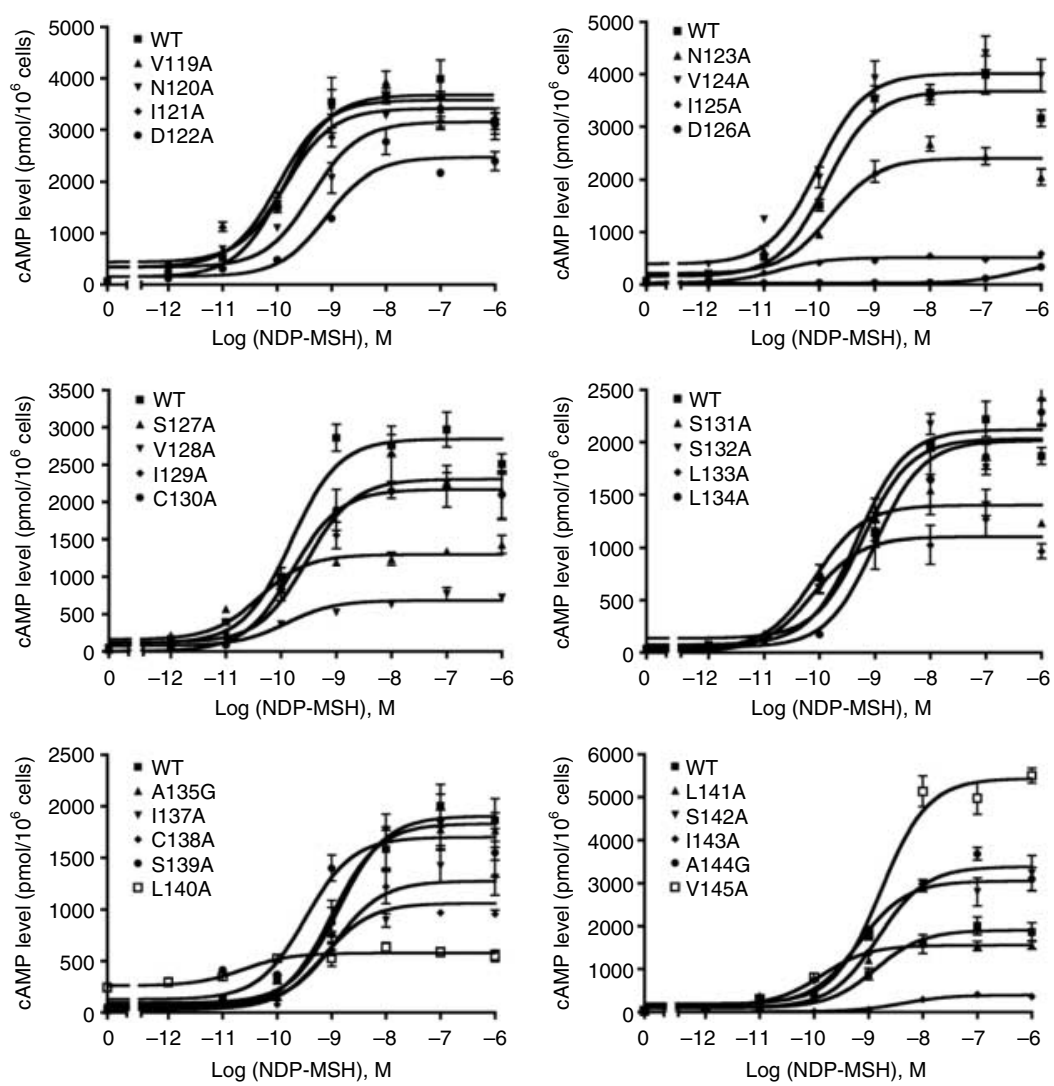

Figure 4 Signaling properties of the WT and mutant hMC4Rs with NDP-MSH as the ligand. Intracellular cAMP levels were measured using RIA as described. Results are expressed as the mean \pm S.E.M. of triplicate determinations within one experiment. All experiments were performed three to five times.

for 5 min with $1 \mu \mathrm{M}$ NDP-MSH (for SDM only) or not. The levels of pERK1/2 were measured using western blots as described in the Materials and methods section.

As shown in Fig. 10A, B and C, although the CAMs had high constitutive activities in the cAMP pathway (Fig. 10A), their basal pERK1/2 activities were at similar levels to that of WT MC4R (Fig. 10B and C), different from their basal cAMP signaling. None of the CAM mutants had increased basal ERK1/2 signaling. Data for the four SDMs are shown in Fig. 11A, B and C. Two mutants (L140I and L140M) were defective in ERK1/2 signaling upon NDP-MSH stimulation, consistent with their deficiency in cAMP production. Two SDMs (L140G and L140R) had similar levels of ERK1/2 phosphorylation as that of WT MC4R upon NDP-MSH stimulation, different from their cAMP signaling properties. It is interesting to note that although L140R had decreased basal cAMP activity (see also Tao (2008)), it had significant constitutive pERK1/2 levels (Fig. 11C). These results suggested that the nine CAMs and two SDMs (L140G and L140R) had divergent cAMP and ERK1/2 signaling properties.

\section{Discussion}

In this study, we systematically studied 26 residues of TM3 in MC4R. We showed that one mutant D126A had no measurable binding, and six other mutants, D122A, I125A, L133A, L134A, S139A, and L140A, had significantly decreased maximal binding or receptor occupancy (Fig. 3 and Table 1). These seven mutants had normal levels of cell-surface expression, suggesting that these mutants were defective in ligand binding per se.

D122, I125, and D126 sit at the top of the third TM domain. We showed that D122A, I125A, and D126A were expressed normally at the cell surface but with significantly decreased ligand binding or cAMP signaling. These results are consistent with previous mutagenesis experiments demonstrating D122, I125, and D126 as being essential for binding to peptide and nonpeptidyl ligands (Yang et al. 2000, Fleck et al. 2005, Hogan et al. 2006), hypothesized to interact with the pharmacophore His-D-Phe-Arg-Trp of NDP-MSH (Hogan et al. 2006, Nargund et al. 2006). We also showed that the naturally occurring D126Y mutation is 


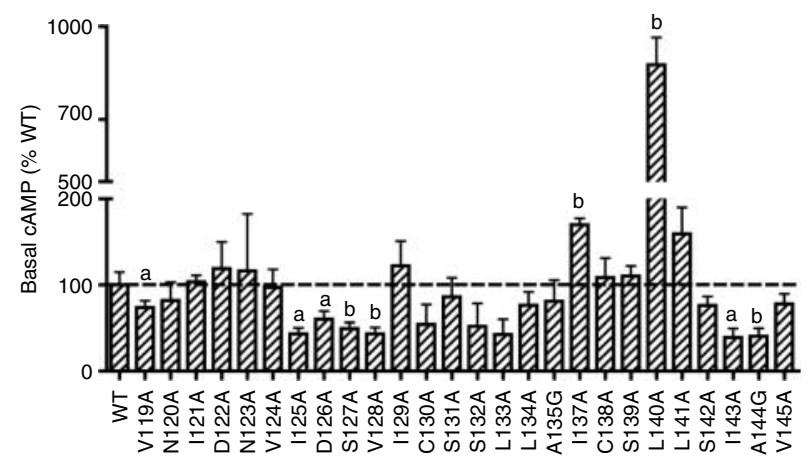

Figure 5 Constitutive activities of the WT and TM3 mutant hMC4Rs. Intracellular basal cAMP levels in cells transiently transfected with WT or mutant hMC4Rs were measured in the absence of any ligand. The results are expressed as percentage of WT basal activity. The basal cAMP levels were $47 \cdot 25 \pm 4 \cdot 98 \mathrm{pmol} / 10^{6}$ cells (mean \pm S.E.M. of 29 experiments). The statistical significance is indicated as follows: ${ }^{a}$ significantly different from WT hMC4R, $P<0.01 ;{ }^{b}$ significantly different from WT hMC4R, $P<0.001$.

expressed normally at the surface but had no binding to NDP-MSH, defective in ligand binding per se (Wang \& Tao 2011).

Four mutants, including L133A, L134A, S139A, and L140A, were expressed on the cell surface normally but had significantly decreased maximal binding (Fig. 2A and Table 1). L133 and L134 are located in the middle of TM3, and S139 and L140 are located near the intracellular surface. Because of the modest decreases in maximal binding without affecting the binding affinity (similar $\mathrm{IC}_{50}$ as the WT MC4R) for L133A and L134A, and the inherent inaccuracies in the binding assay used here for estimating maximal binding, we cannot conclude whether these two residues are directly involved in ligand binding. A previous study mutating L133 to methionine showed that binding to NDP-MSH is not affected (Yang et al. 2002). Mutations of S139 and L140, located close to the intracellular surface of TM3, into alanine, caused dramatic decreases in maximal binding despite normal cell-surface expression. Similar observations were made before in other peptide receptors. For example, in the GNRH receptor, mutations in the cytoplasmic end of TMs were found to affect ligand binding ( $\mathrm{Lu}$ et al. 2005). In the MC3R, we showed that mutations of E92 located near the intracellular end of TM1 abolished ligand binding despite expression at the cell surface (Wang et al. 2008). These mutations likely affected the conformation of the receptor rather than directly disrupted ligand-receptor interaction.

Four mutants, D122A, D126A, L133A, and L140A, had cAMP signaling deficiency, most likely due to their impaired binding properties as discussed earlier. Five mutants, S127A, V128A, S132A, L141A, and I143A, had impaired signaling but normal ligand binding, suggesting that these residues are important in signal transduction. Several previous studies (Hinney et al. 2003, Lubrano-Berthelier et al. 2003, Valli-Jaakola et al. 2004), including ours (Fan \& Tao 2009), showed that one naturally occurring mutation, S127L, has significantly decreased maximal responses and a modest (less than threefold) but significant increase in basal cAMP signaling activity. In our experiments, mutating S127 to Ala resulted in decreased maximal response. However, its basal activity was similar to that of WT MC4R.

We previously reported that one naturally occurring mutation, S136F, is a loss-of-function mutation with normal total and cell-surface expression, as well as normal ligand binding properties (Fan \& Tao 2009), consistent with other studies (Valli-Jaakola et al. 2004, Tan et al. 2009). Multiple mutagenesis experiments further showed that $\mathrm{S} 136$ is important for signaling. We showed that mutating S136 to Ala, Cys, and Arg resulted in decreased maximal response, whereas mutations into Cys, Leu, Arg, and Try resulted in increased $\mathrm{EC}_{50} \mathrm{~S}$ (Fan \& Tao 2009).

The DRY motif and surrounding residues have been known to be essential for receptor signaling in various GPCRs (Gether 2000, Yamano et al. 2004, Govaerts et al. 2005). Mutations in this motif are known to greatly affect the receptor functions by directly disrupting the $\mathrm{G}$ protein coupling and disrupting the ionic lock
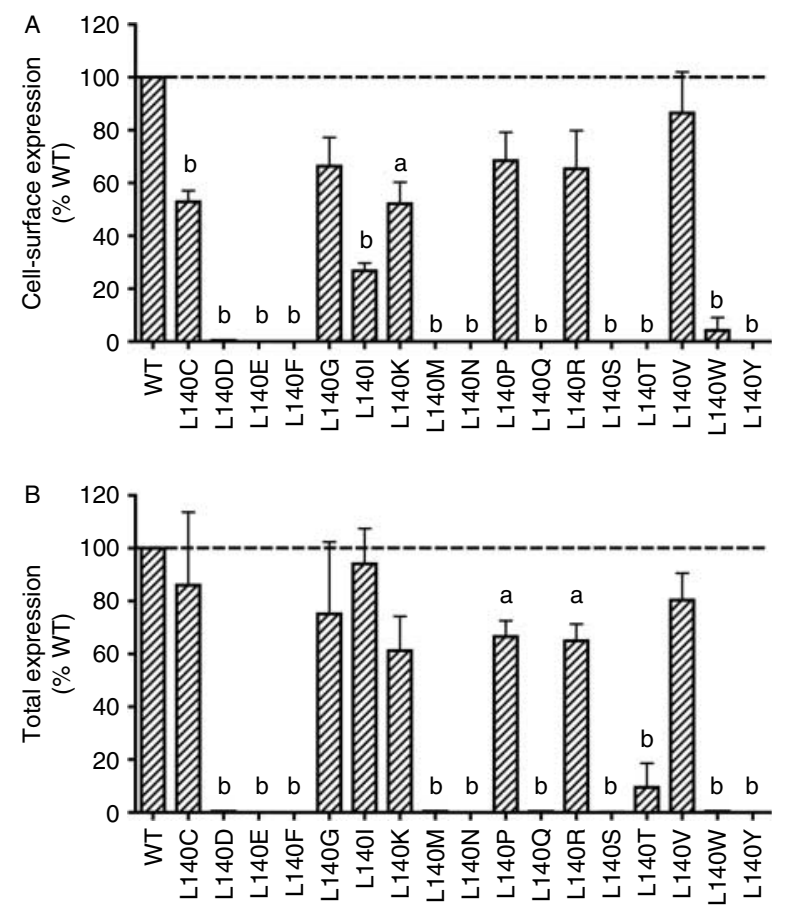

Figure 6 Cell-surface expression (A) and total expression (B) of WT and L140 mutant hMC4Rs measured by flow cytometry. See the legend to Fig. 2 for details. The statistical significance is indicated as follows: a significantly different from WT hMC4R,

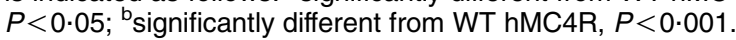




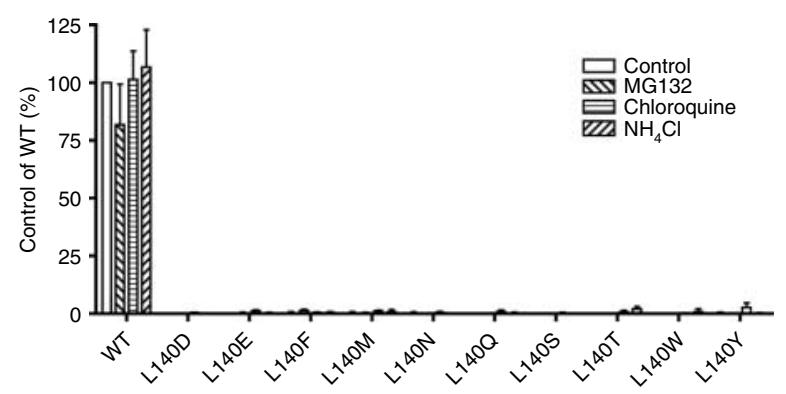

Figure 7 Total receptor expression of WT and ten L140 hMC4R mutants, that with totally abolished total receptor expression, measured by flow cytometry with or without the treatment of proteasome inhibitor ( $25 \mu \mathrm{M}$ MG132), or lysosome inhibitors (25 $\mathrm{mM} \mathrm{NH}_{4} \mathrm{Cl}$ or $100 \mu \mathrm{M}$ chloroquine).

formed between TM3 and TM6 (reviewed in Gether (2000)). In the MC4R, mutations of the DRY motif resulted in profoundly impaired ligand binding and receptor signaling properties (Yamano et al. 2004). Previous studies mutating D146 into Ala resulted in significantly increased basal cAMP activity. We also reported that one naturally occurring mutation, D146N, has increased basal cAMP activity with decreased cell-surface expression, decreased ligand binding but normal maximal responses (Tao et al. 2010, Wang \& Tao 2011). T150I in the DRYxxI motif has significantly decreased receptor signaling (Govaerts et al. 2005). We showed that I151 in the DRYxxI motif at the end of TM3 is also critical for ligand-induced cAMP signaling; mutation of this isoleucine to asparagine totally disrupts NDP-MSH-induced signaling despite normal ligand binding (Tao \& Segaloff 2004).

The remaining mutants could signal at least as well as WT MC4R in terms of maximal signaling upon
NDP-MSH stimulation, consistent with several previous studies (Yang et al. 2000, Chen et al. 2007). Three mutants, S142A, A144G, and V145A, even had significantly increased maximal response. Similar observations were made before in other mutant MC4Rs (Wang \& Tao 2011).

We also showed that one mutant, I121A, had normal cell-surface expression, ligand binding, and cAMP signaling. Some previous studies demonstrated that one naturally occurring mutation, I121T, is impaired in cAMP signaling upon stimulation with $\alpha$-MSH (Hinney et al. 2003). Recent studies, however, showed that I121T has decreased cell-surface expression, decreased binding affinity with NDP-MSH, but normal potency upon $\alpha$-MSH or NDP-MSH stimulation (Xiang et al. 2010). Therefore, the structure-function relationship of the residue I121 is still unclear.

In addition, our data showed that one mutant, I137A, normally expressed on the cell surface, had normal binding and signaling properties. In previous studies, one naturally occurring mutation, I137T, has been shown to be expressed on the cell surface but defective in agonist binding (Gu et al. 1999).

Basal signaling of the MC4R has been suggested to be important for maintaining energy homeostasis in humans (Srinivasan et al. 2004). We have also identified a number of naturally occurring MCAR mutations that have decreased basal activities (Tao \& Segaloff 2005, Fan \& Tao 2009, Wang \& Tao 2011). In this study, we also measured the basal signaling of the mutant MC4Rs. We showed that two mutants, $\mathrm{I} 1377^{3} \cdot{ }^{40} \mathrm{~A}$ and $\mathrm{L} 140^{3} \cdot{ }^{43} \mathrm{~A}$, had significantly increased basal signaling. These results are consistent with the crystal structure of $\beta_{2}$-adrenoceptor, showing that $1121^{3}{ }^{3.0}$ (Rasmussen et al. 2011) and L124. ${ }^{3.43}$ (Rosenbaum et al. 2007) are
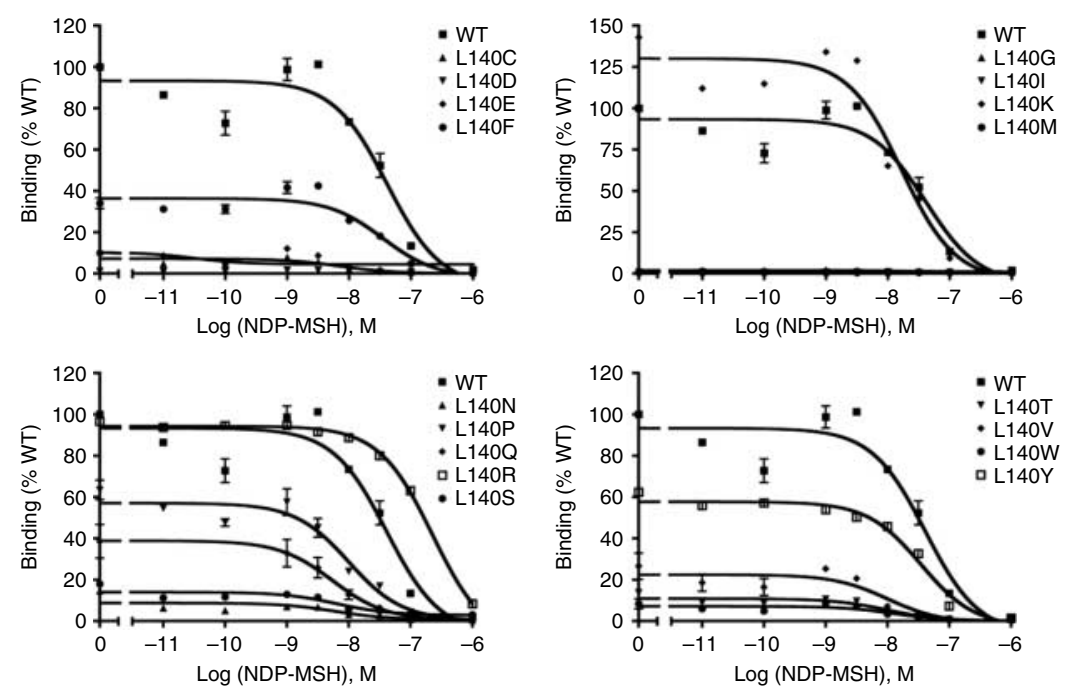

Figure 8 Ligand binding properties of the WT and L140 mutants with NDP-MSH as the ligand. See the legend to Fig. 3 for details. 
Table 2 NDP-MSH-stimulated signaling and ligand binding of WT and L140 mutants. The data were expressed as the mean \pm S.E.M. of three independent experiments for the mutant hMC4Rs. The maximal responses $\left(R_{\max }\right)$ were $2509 \cdot 55 \pm 160 \cdot 14 \mathrm{pmol}$ cAMP $/ 10^{6}$ cells for WT hMC4R

\begin{tabular}{|c|c|c|c|c|c|c|}
\hline \multirow[b]{2}{*}{ hMC4R } & \multirow[b]{2}{*}{$n$} & \multirow[b]{2}{*}{ Basal cAMP (\% WT) } & \multicolumn{2}{|c|}{ NDP-MSH binding } & \multicolumn{2}{|c|}{ NDP-MSH-stimulated cAMP } \\
\hline & & & $\mathrm{IC}_{50}(\mathrm{nM})$ & $B_{\max }(\% \mathrm{WT})$ & $\mathrm{EC}_{50}(\mathrm{nM})$ & $R_{\max }(\% \mathrm{WT})$ \\
\hline WT & 29 & $100 \cdot 00$ & $108 \cdot 83 \pm 22 \cdot 60$ & 100 & $0.51 \pm 0.07$ & 100 \\
\hline L140C & 3 & $1832 \cdot 12 \pm 303 \cdot 62^{\mathrm{a}}$ & $7 \cdot 82 \pm 0 \cdot 67^{b}$ & $6.99 \pm 0.99^{c}$ & $21 \cdot 05 \pm 6 \cdot 85^{b}$ & $65 \cdot 36 \pm 7 \cdot 54^{a}$ \\
\hline L140D & 3 & $208 \cdot 35 \pm 17 \cdot 77^{\mathrm{a}}$ & $\overline{N D}$ & $8 \cdot 83 \pm 4 \cdot 88^{c}$ & $1 \cdot 15 \pm 0 \cdot 86$ & $40 \cdot 03 \pm 3.88^{c}$ \\
\hline L140E & 3 & $1576 \cdot 81 \pm 37 \cdot 80^{c}$ & $5 \cdot 04 \pm 0 \cdot 71^{b}$ & $15 \cdot 76 \pm 3 \cdot 17^{c}$ & $0.63 \pm 0.18$ & $86.97 \pm 6 \cdot 67$ \\
\hline L140F & 3 & $67 \cdot 73 \pm 26 \cdot 97$ & $31 \cdot 68 \pm 12 \cdot 74$ & $46 \cdot 49 \pm 7 \cdot 29^{a}$ & $14 \cdot 12 \pm 1 \cdot 70^{\mathrm{a}}$ & $69 \cdot 75 \pm 3 \cdot 67^{a}$ \\
\hline L140G & 3 & $84 \cdot 11 \pm 7 \cdot 40$ & $13 \cdot 70 \pm 2 \cdot 84$ & $8 \cdot 05 \pm 5 \cdot 90^{c}$ & $2 \cdot 20 \pm 0.54^{b}$ & $20 \cdot 82 \pm 0.27^{c}$ \\
\hline L140I & 3 & $49 \cdot 75 \pm 8 \cdot 02^{a}$ & ND & ND & ND & ND \\
\hline L140K & 3 & $643 \cdot 25 \pm 15 \cdot 17^{c}$ & $11 \cdot 81 \pm 2 \cdot 62$ & $129 \cdot 16 \pm 5 \cdot 09^{a}$ & $3 \cdot 45 \pm 2 \cdot 19$ & $95.94 \pm 2.06$ \\
\hline L140M & 3 & $21 \cdot 21 \pm 3 \cdot 63^{\mathrm{C}}$ & ND & ND & ND & ND \\
\hline L140N & 3 & $2693 \cdot 38 \pm 566 \cdot 11^{a}$ & $5.57 \pm 0.93^{b}$ & $18 \cdot 27 \pm 4 \cdot 54^{\mathrm{C}}$ & $0.27 \pm 0.11$ & $64 \cdot 23 \pm 4 \cdot 67^{\mathrm{a}}$ \\
\hline L140P & 3 & $1227 \cdot 83 \pm 266 \cdot 28^{a}$ & $19 \cdot 38 \pm 10 \cdot 35$ & $136 \cdot 90 \pm 42 \cdot 12$ & $1.65 \pm 0.98$ & $113 \cdot 44 \pm 9.47$ \\
\hline L140Q & 3 & $1997 \cdot 89 \pm 800 \cdot 82$ & $10 \cdot 19 \pm 3 \cdot 61^{\mathrm{b}}$ & $47 \cdot 32 \pm 5 \cdot 23^{c}$ & $1 \cdot 28 \pm 0.07^{a}$ & $75 \cdot 61 \pm 13 \cdot 88$ \\
\hline L140R & 3 & $51 \cdot 17 \pm 4 \cdot 85^{\mathrm{a}}$ & $161 \cdot 35 \pm 40 \cdot 70$ & $97 \cdot 04 \pm 5 \cdot 04$ & $1 \cdot 23 \pm 0 \cdot 11^{\mathrm{b}}$ & $45 \cdot 09 \pm 2 \cdot 07^{a}$ \\
\hline L140S & 3 & $1696 \cdot 26 \pm 448 \cdot 25^{b}$ & $22 \cdot 45 \pm 14 \cdot 33$ & $10 \cdot 53 \pm 4.95^{c}$ & $1.56 \pm 0.76$ & $44 \cdot 36 \pm 9 \cdot 81^{a}$ \\
\hline L140T & 3 & $2868 \cdot 03 \pm 903 \cdot 00^{b}$ & $8 \cdot 83 \pm 0 \cdot 72^{b}$ & $20 \cdot 45 \pm 6 \cdot 40^{\mathrm{C}}$ & $40 \cdot 74 \pm 5 \cdot 43^{a}$ & $96 \cdot 89 \pm 5 \cdot 16$ \\
\hline L140V & 3 & $1830 \cdot 42 \pm 440 \cdot 04^{\mathrm{b}}$ & $7 \cdot 60 \pm 1 \cdot 20^{b}$ & $45 \cdot 98 \pm 13 \cdot 27^{b}$ & $0.27 \pm 0.03^{b}$ & $103.55 \pm 9.33$ \\
\hline L140W & 3 & $62 \cdot 82 \pm 16 \cdot 90$ & $15 \cdot 62 \pm 1 \cdot 31^{b}$ & $9 \cdot 32 \pm 1 \cdot 69^{c}$ & $8 \cdot 87 \pm 3 \cdot 24$ & $103 \cdot 03 \pm 2.45$ \\
\hline L140Y & 3 & $32 \cdot 84 \pm 9 \cdot 61^{a}$ & $24 \cdot 45 \pm 5 \cdot 20$ & $54 \cdot 91 \pm 10 \cdot 05^{\mathrm{a}}$ & $29 \cdot 56 \pm 7 \cdot 97^{b}$ & $88 \cdot 28 \pm 5 \cdot 19$ \\
\hline
\end{tabular}

ND, could not be detected.

aSignificantly different from corresponding WT receptor, $P<0 \cdot 01$.

${ }^{\mathrm{b}}$ Significantly different from corresponding WT receptor, $P<0.05$.

'Significantly different from corresponding WT receptor, $P<0.001$.

essential for stabilizing the receptor in its inactive conformation, hypothesized to interact with other residues through hydrophobic interactions.

In order to obtain more detailed insight into the function of L140 in MC4R, we generated 17 additional L140 mutants. We showed that ten L140 mutants were constitutively active in cAMP signaling, including substitutions of L140 to three hydrophobic residues $(\mathrm{C}, \mathrm{P}$, and $\mathrm{V})$, four hydrophilic neutral residues $(\mathrm{N}, \mathrm{Q}$, $\mathrm{S}$, and $\mathrm{T}$ ), two hydrophilic negatively charged residues (D and $\mathrm{E}$ ), and one hydrophilic positively charged residue (K). Seven L140 mutants had normal
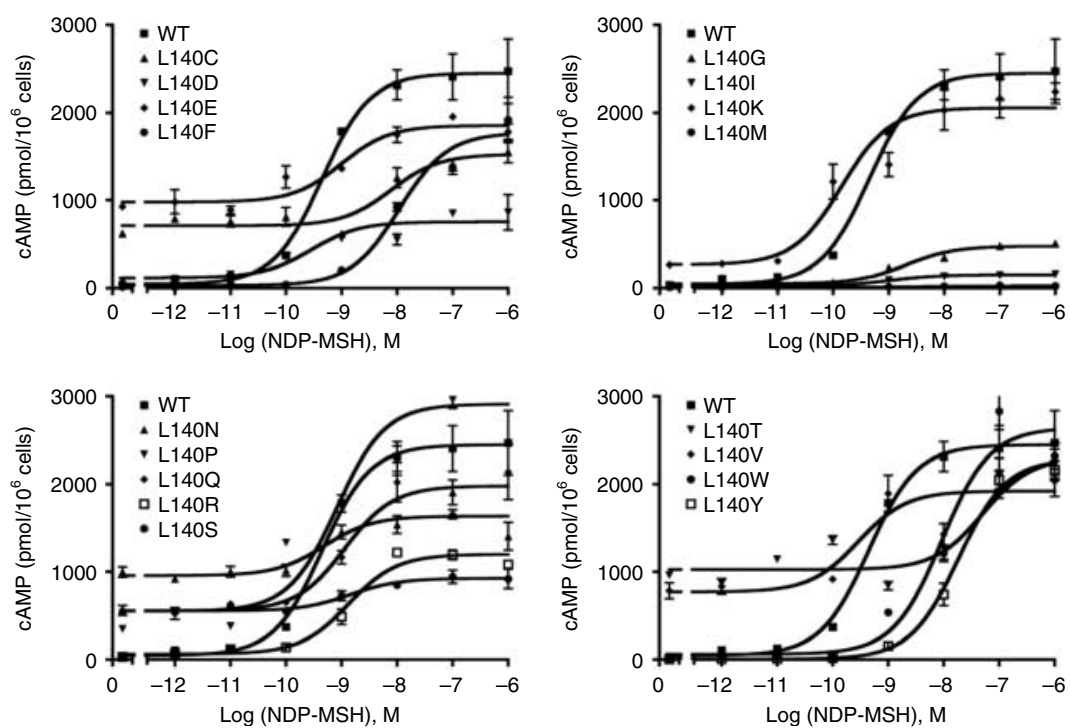

Figure 9 Signaling properties of the WT and L140 mutants with NDP-MSH as the ligand. See the legend to Fig. 4 for details. 

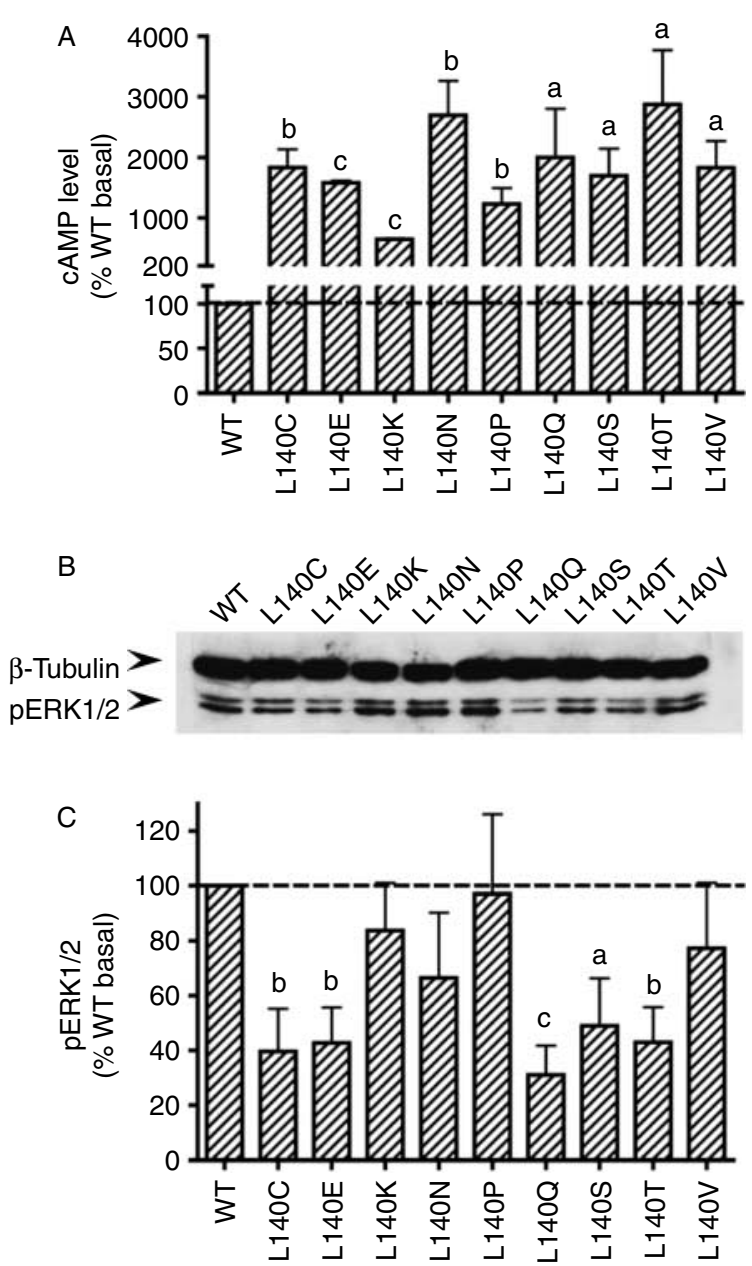

Figure 10 cAMP and ERK $1 / 2$ signaling of WT and constitutively active $\mathrm{L} 140$ mutants. cAMP accumulation $(\mathrm{A})$ and ERK1/2 phosphorylation ( $\mathrm{B}$ and $\mathrm{C}$ ) were assessed after a $1-\mathrm{h}$ and a 5-min incubation as described in the Materials and methods section. Results are expressed as percentage of the value obtained in nonstimulated WT MC4R cells and represent the mean \pm S.E.M. of three independent experiments. The statistical significance is indicated as follows: ${ }^{a}$ significantly different from WT hMC4R,

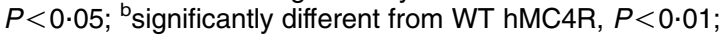
csignificantly different from WT hMC4R, $P<0.001$.

or even decreased basal cAMP activity, including substitutions of L140 to one hydrophilic positively charged residue $(\mathrm{R})$ and six hydrophobic residues $(\mathrm{F}$, $\mathrm{G}, \mathrm{I}, \mathrm{M}, \mathrm{W}$, and $\mathrm{Y}$ ).

Correlation analyses demonstrated that the basal cAMP activity was significantly correlated with the hydrophobicity (Jones 1975) of the residues (Pearson's correlation coefficients $=-0.5523, P$ value $=0.0142)$. This result was consistent with the previous finding in the crystal structure of $\beta_{2}$-adrenoceptor that a hydrophobic pocket is formed around Leu124 ${ }^{3}{ }^{43}$ (Rosenbaum et al. 2007). Four mutants (L140 to C, P, $\mathrm{R}$, and $\mathrm{V}$ ), however, were exceptions that cannot be fully explained by the hypothesis that constitutive activation resulted from the disruption of hydrophobic interactions that stabilize the receptor in its inactive state. Rather, in these cases, a more likely hypothesis is that constitutive activity arises from the disruption of interhelical interactions stabilizing the inactive conformation as well as formation of other interactions involving the newly introduced residue, which can stabilize the receptor in an active state (Tao et al. 2000).

With the recent report that ERK1/2 signaling activated through MC4R is involved in melanocortininduced decreases in food intake (Sutton et al. 2005), herein, we studied the ERK1/2 signaling of nine CAMs and four SDMs at the L140 locus. We demonstrated that two SDMs (L140I and L140M) had similar ERK1/2 activities as their cAMP signaling properties. The other two SDMs (L140 to G and R) had normal ERK1/2 phosphorylation upon stimulation. L140R had decreased basal cAMP activity but had significant constitutive activity in the basal ERK1/2 signaling pathway. All nine L140 CAMs (L140 to C, E, K, N, P, $\mathrm{Q}, \mathrm{S}, \mathrm{T}$, and $\mathrm{V}$ ) had no constitutive activation of ERK1/2 signaling. Therefore, we concluded that one mutant, L140G, was intrinsically biased in the ERK1/2 signaling pathway. One mutant, L140R, was intrinsically biased in basal cAMP signaling and was intrinsically biased in ERK1/2 signaling upon NDP-MSH stimulation. Nine mutants, mutations L140 to C, E, K, N, P, Q, S, T, and $\mathrm{V}$, were intrinsically biased MC4R mutants in basal cAMP signaling.

Several intrinsically biased GPCR mutants have been reported. For example, a mutant angiotensin type 1A receptor (DRY/AAY) is intrinsically biased in ERK1/2 signaling upon agonist stimulation (Wei et al. 2003). Transgenic mice with this mutant receptor develop more severe hypertrophy and bradycardia than WT mice (Zhai et al. 2005). One mutant $\beta_{2}$-adrenoceptor (T68F, Y132G, and Y219A) is also intrinsically biased in the ERK1/2 signaling pathway (Shenoy et al. 2006). In the MC4R, Patten et al. (2007) reported the first MC4R mutant, D298N, which is intrinsically biased in cAMP signaling. It was shown that D298N has cAMP signaling but does not have ERK1/2 signaling upon hormone stimulation. To our best knowledge, we are the first to report mutant MC4Rs (mutations of L140 to C, E, K, N, P, Q, S, T, and V) that were intrinsically biased in basal cAMP signaling, as well as the first to report mutant MC4Rs (L140G and L140R) that were intrinsically biased in the ERK1/2 signaling pathway upon agonist stimulation.

The studies of biased agonism in other GPCRs have suggested that divergent signaling pathways might contribute to different physiological functions (reviewed in Whalen et al. (2011)). The MC4R has multiple physiological roles in regulating energy homeostasis, cachexia, cardiovascular function, glucose and lipid homeostasis, reproduction, and sexual 


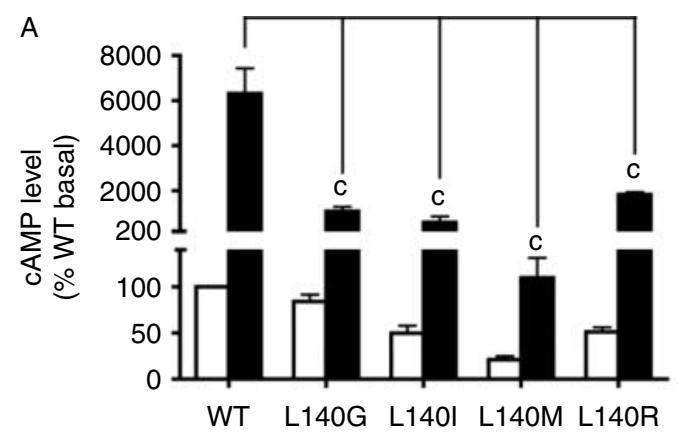

B WT L140G L140I L140M L140R
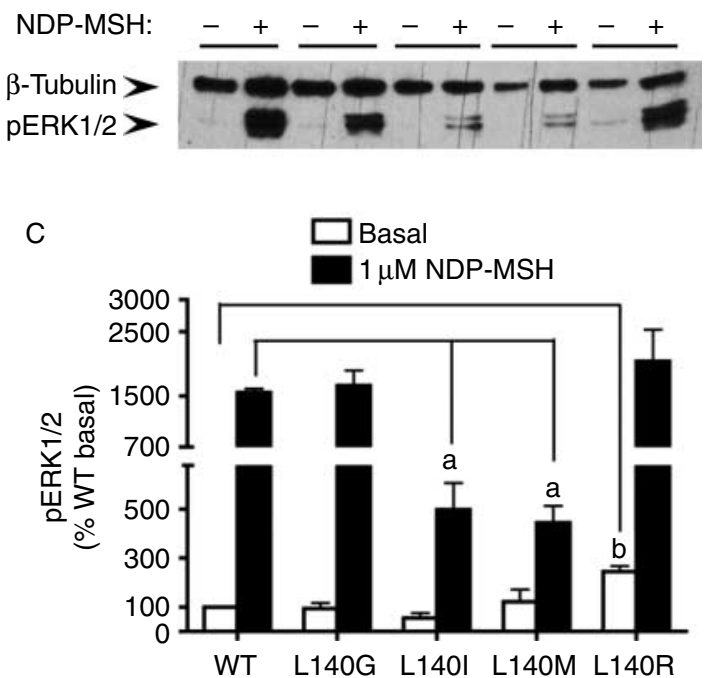

Figure 11 cAMP and ERK $1 / 2$ signaling of WT and signal defective L140 mutants. cAMP accumulation (A) and ERK1/2 phosphorylation ( $B$ and $C$ ) were assessed as described in the Materials and methods section. See the legend to Fig. 10 for details.

function (Tao 2010). The signaling pathways activated in different physiological functions of MC4R, however, has not been determined. The intrinsically biased MC4R mutant constructs reported in this study could be useful for generating transgenic animals and thus be helpful in investigating the potential role of cAMPdependent or ERK1/2-dependent signaling pathway in mediating the physiological roles of the MC4R.

GPCRs have been known to have multiple signaling states, and a mutant receptor can adopt a specific conformation (reviewed in Perez \& Karnik (2005)). Our data suggested that the nine L140 CAMs might stabilize the MC4R in a conformation capable of coupling to cAMP but not to the ERK1/2 signaling pathway. The two L140 SDMs (L140 to G and R) might stabilize the MC4R in a conformation capable of coupling to ERK1/2 but not to the cAMP signaling pathway upon NDP-MSH stimulation. The SDM L140R might stabilize the MC4R in a conformation that constitutively activates ERK1/2 but not cAMP signaling.
Our results further confirmed the divergent structural requirement for the cAMP and ERK1/2 signaling pathways and suggested that L140 might be a key residue in switching MC4R between several thermodynamically favorable conformations.

The flow cytometry results showed that three mutants, L140C, L140I, and L140K, were intracellularly retained with decreased cell-surface expression but normal total receptor expression, suggesting that these mutants are defective in forward trafficking. Defective trafficking of mutant receptors to the cell surface has been shown to be a predominant defect in MC4R as well as in other GPCR mutations (reviewed in Conn et al. (2007) and Tao (2005, 2006)). Interestingly, however, one TM3 mutant (I129A) and 12 L140 mutants (mutating L140 to D, E, F, M, N, P, Q, R, S, T, W, and Y) had dramatic decreases in total receptor expression.

Decreased total receptor expression has been reported previously for some missense GPCR mutations including the MC4R (Fan \& Tao 2009, Wang \& Tao 2011, Yang \& Tao 2012, Zhang et al. 2012), even for some synonymous mutations (Duan et al. 2003, Bartoszewski et al. 2010). We therefore further studied whether the decreased total receptor expression was due to accelerated protein degradation (Yang et al. 2011). Ten L140 mutants (mutating L140 to D, E, F, M, $\mathrm{N}, \mathrm{Q}, \mathrm{S}, \mathrm{T}, \mathrm{W}$, and $\mathrm{Y}$ ) had almost abolished total receptor expression. Their total expression levels were measured with or without the treatment of proteasome inhibitor or lysosome inhibitors. The results (as shown in Fig. 7), however, showed that there was no increase in total receptor expression upon the treatment of proteasome or lysosome inhibitors. These results suggested that increased degradation by the proteasome or lysosome was not responsible for the diminished expression of these mutants. Decreased protein synthesis due to altered secondary structure of mRNA (Duan et al. 2003, Bartoszewski et al. 2010) of those MC4R mutants might be responsible for the decreased receptor expression, although posttranscriptional mechanisms might also be involved. Further studies are needed to address the detailed causes of the observed decreased total MC4R expression.

In summary, the results presented here showed that TM3 was critical for MC4R ligand binding and/or signaling, consistent with previous studies. Of the 26 TM3 mutants we studied herein, 13 were significantly impaired in ligand binding and/or cAMP signaling. Moreover, L140 was critical for locking MC4R in inactive conformation and several mutants displayed biased signaling in cAMP and ERK1/2 signaling pathways.

\section{Declaration of interest}

The authors declare that there is no conflict of interest that could be perceived as prejudicing the impartiality of the research reported. 


\section{Funding}

This study was supported by grants from the National Institutes of Health R15DK077213, American Diabetes Association Grant 1-12-BS212, and Animal Health and Diseases Research Program as well as Interdisciplinary Grant from Auburn University College of Veterinary Medicine.

\section{Acknowledgements}

The authors thank Dr Ira Gantz for generously providing the wild-type MC4R construct. The 9E10 c-myc antibody and E7 $\beta$-tubulin antibody developed by J M Bishop and M Klymkowsky respectively were obtained from the Developmental Studies Hybridoma Bank developed under the auspices of the NICHD and maintained by the Department of Biology, University of Iowa, Iowa City, IA 52242, USA.

\section{References}

Ballesteros JA \& Weinstein H 1995 Integrated methods for the construction of three-dimensional models and computational probing of structure-function relations in $\mathrm{G}$ protein-coupled receptors. Methods in Neurosciences 25 366-428. (doi:10.1016/S10439471(05)80049-7)

Ballesteros JA, Jensen AD, Liapakis G, Rasmussen SGF, Shi L, Gether U $\&$ Javitch JA 2001 Activation of the $\beta_{2}$-adrenergic receptor involves disruption of an ionic lock between the cytoplasmic ends of transmembrane segments 3 and 6. Journal of Biological Chemistry 276 29171-29177. (doi:10.1074/jbc.M103747200)

Baranski TJ, Herzmark P, Lichtarge O, Gerber BO, Trueheart J, Meng EC, Iiri T, Sheikh SP \& Bourne HR 1999 C5a receptor activation: genetic identification of critical residues in four transmembrane helices. Journal of Biological Chemistry 274 15757-15765. (doi:10.1074/jbc.274.22.15757)

Bartoszewski RA, Jablonsky M, Bartoszewska S, Stevenson L, Dai Q, Kappes J, Collawn JF \& Bebok Z 2010 A synonymous single nucleotide polymorphism in $\triangle$ F508 CFTR alters the secondary structure of the mRNA and the expression of the mutant protein. Journal of Biological Chemistry 285 28741-28748. (doi:10.1074/jbc. M110.154575)

Bhargava SK, Sachdev HS, Fall CHD, Osmond C, Lakshmy R, Barker DJP, Biswas SKD, Ramji S, Prabhakaran D \& Reddy KS 2004 Relation of serial changes in childhood body-mass index to impaired glucose tolerance in young adulthood. New England Journal of Medicine 350 865-875. (doi:10.1056/NEJMoa035698)

Chen C \& Okayama H 1987 High-efficiency transformation of mammalian-cells by plasmid DNA. Molecular and Cellular Biology 7 2745-2752. (doi:10.1128/MCB.7.8.2745)

Chen M, Cai MY, Aprahamian CJ, Georgeson KE, Hruby V, Harmon CM \& Yang YK 2007 Contribution of the conserved amino acids of the melanocortin- 4 receptor in $\left[\mathrm{Nle}^{4}, \mathrm{D}-\mathrm{Phe}^{7}\right]-\alpha-$ melanocyte-stimulating hormone binding and signaling. Journal of Biological Chemistry 282 21712-21719. (doi:10.1074/jbc. M702285200)

Cherezov V, Rosenbaum DM, Hanson MA, Rasmussen SGF, Thian FS, Kobilka TS, Choi HJ, Kuhn P, Weis WI, Kobilka BK et al. 2007 Highresolution crystal structure of an engineered human $\beta_{2}$-adrenergic G protein-coupled receptor. Science 318 1258-1265. (doi:10.1126/ science.1150577)

Conn PM, Ulloa-Aguirre A, Ito J \& Janovick JA 2007 G protein-coupled receptor trafficking in health and disease: lessons learned to prepare for therapeutic mutant rescue in vivo. Pharmacological Reviews 59 225-250. (doi:10.1124/pr.59.3.2)
Daniels D, Patten CS, Roth JD, Yee DK \& Fluharty SJ 2003 Melanocortin receptor signaling kinase in vitro and through mitogen-activated protein in rat hypothalamus. Brain Research 986 1-11. (doi:10.1016/S0006-8993(03)03162-7)

Duan JB, Wainwright MS, Comeron JM, Saitou N, Sanders AR, Gelernter J \& Gejman PV 2003 Synonymous mutations in the human dopamine receptor D2 (DRD2) affect mRNA stability and synthesis of the receptor. Human Molecular Genetics 12 205-216. (doi:10.1093/hmg/ddg055)

Fan ZC \& Tao YX 2009 Functional characterization and pharmacological rescue of melanocortin-4 receptor mutations identified from obese patients. Journal of Cellular and Molecular Medicine 13 3268-3282. (doi:10.1111/j.1582-4934.2009.00726.x)

Fan W, Boston BA, Kesterson RA, Hruby VJ \& Cone RD 1997 Role of melanocortinergic neurons in feeding and the agouti obesity syndrome. Nature 385 165-168. (doi:10.1038/385165a0)

Fan ZC, Sartin JL \& Tao YX 2008 Molecular cloning and pharmacological characterization of porcine melanocortin-3 receptor. Journal of Endocrinology 196 139-148. (doi:10.1677/JOE-070403)

Farooqi IS, Keogh JM, Yeo GSH, Lank EJ, Cheetham T \& O'Rahilly S 2003 Clinical spectrum of obesity and mutations in the melanocortin 4 receptor gene. New England Journal of Medicine 348 1085-1095. (doi:10.1056/NEJMoa022050)

Farrens DL, Altenbach C, Yang K, Hubbell WL \& Khorana HG 1996 Requirement of rigid-body motion of transmembrane helices for light activation of rhodopsin. Science 274 768-770. (doi:10.1126/ science.274.5288.768)

Fleck BA, Chen C, Yang WD, Huntley R, Markison S, Nickolls SA, Foster AC \& Hoare SRJ 2005 Molecular interactions of nonpeptide agonists and antagonists with the melanocortin-4 receptor. Biochemistry 44 14494-14508. (doi:10.1021/bi051316s)

Flegal KM, Carroll MD, Kit BK \& Ogden CL 2012 Prevalence of obesity and trends in the distribution of body mass index among US adults, 1999-2010. Journal of the American Medical Association 307 491-497. (doi:10.1001/jama.2012.39)

Fong TM, Mao C, MacNeil T, Kalyani R, Smith T, Weinberg D, Tota MR \& Van Der Ploeg LHT 1997 ART (protein product of agouti-related transcript) as an antagonist of MC-3 and MC-4 receptors. Biochemical and Biophysical Research Communications 237 629-631. (doi:10.1006/ bbrc.1997.7200)

Gantz I, Miwa H, Konda Y, Shimoto Y, Tashiro T, Watson SJ, Delvalle J \& Yamada T 1993 Molecular cloning, expression, and gene localization of a fourth melanocortin receptor. Journal of Biological Chemistry 268 15174-15179.

Gether U 2000 Uncovering molecular mechanisms involved in activation of G protein-coupled receptors. Endocrine Reviews 21 90-113. (doi:10.1210/er.21.1.90)

Gether U, Lin S, Ghanouni P, Ballesteros JA, Weinstein H \& Kobilka BK 1997 Agonists induce conformational changes in transmembrane domains III and VI of the $\beta_{2}$-adrenoceptor. EMBO Journal 16 6737-6747. (doi:10.1093/emboj/16.22.6737)

Govaerts C, Srinivasan S, Shapiro A, Zhang SM, Picard F, Clement K, Lubrano-Berthelier C \& Vaisse C 2005 Obesity-associated mutations in the melanocortin 4 receptor provide novel insights into its function. Peptides 26 1909-1919. (doi:10.1016/j.peptides.2004.11. 042)

Gu W, Tu Z, Kleyn PW, Kissebah A, Duprat L, Lee J, Chin W, Maruti S, Deng N, Fisher SL et al. 1999 Identification and functional analysis of novel human melanocortin-4 receptor variants. Diabetes $\mathbf{4 8}$ 635-639. (doi:10.2337/diabetes.48.3.635)

Haskell-Luevano C, Cone RD, Monck EK \& Wan YP 2001 Structure activity studies of the melanocortin- 4 receptor by in vitro mutagenesis: identification of agouti-related protein (AGRP), melanocortin agonist and synthetic peptide antagonist interaction determinants. Biochemistry 40 6164-6179. (doi:10.1021/ bi010025q) 
Hinney A, Hohmann S, Geller F, Vogel C, Hess C, Wermter AK, Brokamp B, Goldschmidt H, Siegfried W, Remschmidt H et al. 2003 Melanocortin-4 receptor gene: case-control study and transmission disequilibrium test confirm that functionally relevant mutations are compatible with a major gene effect for extreme obesity. Journal of Clinical Endocrinology and Metabolism 88 4258-4267. (doi:10.1210/jc. 2003-030233)

Hogan K, Peluso S, Gould S, Parsons I, Ryan D, Wu LJ \& Visiers I 2006 Mapping the binding site of melanocortin 4 receptor agonists: a hydrophobic pocket formed by I3.28(125), I3.32(129), and I7.42(291) is critical for receptor activation. Journal of Medicinal Chemistry 49 911-922. (doi:10.1021/jm050780s)

Huszar D, Lynch CA, Fairchild-Huntress V, Dunmore JH, Fang Q, Berkemeier LR, Gu W, Kesterson RA, Boston BA, Cone RD et al. 1997 Targeted disruption of the melanocortin-4 receptor results in obesity in mice. Cell 88 131-141. (doi:10.1016/S0092-8674(00) 81865-6)

Jaakola VP, Griffith MT, Hanson MA, Cherezov V, Chien EYT, Lane JR, Ijzerman AP \& Stevens RC 2008 The 2.6 angstrom crystal structure of a human $\mathrm{A}(2 \mathrm{~A})$ adenosine receptor bound to an antagonist. Science 322 1211-1217. (doi:10.1126/science.1164772)

Jones DD 1975 Amino acid properties and side-chain orientation in proteins: a cross correlation approach. Journal of Theoretical Biology 50 167-183. (doi:10.1016/0022-5193(75)90031-4)

Kosugi S, Hai N, Okamoto H, Sugawa H \& Mori T 2000 A novel activating mutation in the thyrotropin receptor gene in an autonomously functioning thyroid nodule developed by a Japanese patient. European Journal of Endocrinology 143 471-477. (doi:10.1530/eje.0.1430471)

Lagerstrom MC, Klovins J, Fredriksson R, Fridmanis D, Haitina T, Ling MK, Berglund MM \& Schioth HB 2003 High affinity agonistic metal ion binding sites within the melanocortin 4 receptor illustrate conformational change of transmembrane region 3. Journal of Biological Chemistry 278 51521-51526. (doi:10.1074/jbc. M307683200)

Latronico AC, Abell AN, Arnhold IJP, Liu X, Lins TSS, Brito VN, Billerbeck AE, Segaloff DL \& Mendonca BB 1998 A unique constitutively activating mutation in third transmembrane helix of luteinizing hormone receptor causes sporadic male gonadotropin-independent precocious puberty. Journal of Clinical Endocrinology and Metabolism 83 2435-2440. (doi:10.1210/ jc.83.7.2435)

Lu ZL \& Hulme EC 1999 The functional topography of transmembrane domain 3 of the M-1 muscarinic acetylcholine receptor, revealed by scanning mutagenesis. Journal of Biological Chemistry 274 7309-7315. (doi:10.1074/jbc.274.11.7309)

Lu ZL, Gallagher R, Sellar R, Coetsee M \& Millar RP 2005 Mutations remote from the human gonadotropin-releasing hormone (GnRH) receptor-binding sites specifically increase binding affinity for GnRH II but not GnRH I: evidence for ligand-selective, receptor-active conformations. Journal of Biological Chemistry 280 29796-29803. (doi:10.1074/jbc.M413520200)

Lubrano-Berthelier C, Durand E, Dubern B, Shapiro A, Dazin P, Weill J, Ferron C, Froguel P \& Vaisse C 2003 Intracellular retention is a common characteristic of childhood obesity-associated MC4R mutations. Human Molecular Genetics 12 145-153. (doi:10.1093/ $\mathrm{hmg} / \mathrm{ddg} 016)$

Mirzadegan T, Benko G, Filipek S \& Palczewski K 2003 Sequence analyses of G-protein-coupled receptors: similarities to rhodopsin. Biochemistry 42 2759-2767. (doi:10.1021/bi027224+)

Nargund RP, Strack AM \& Fong TM 2006 Melanocortin-4 receptor (MC4R) agonists for the treatment of obesity. Journal of Medicinal Chemistry 49 4035-4043. (doi:10.1021/jm058241a)

Ollmann MM, Wilson BD, Yang YK, Kerns JA, Chen YR, Gantz I \& Barsh GS 1997 Antagonism of central melanocortin receptors in vitro and in vivo by agouti-related protein. Science 278 135-138. (doi:10.1126/science.278.5335.135)
Palczewski K, Kumasaka T, Hori T, Behnke CA, Motoshima H, Fox BA, Le Trong I, Teller DC, Okada T, Stenkamp RE et al. 2000 Crystal structure of rhodopsin: a G protein-coupled receptor. Science $\mathbf{2 8 9}$ 739-745. (doi:10.1126/science.289.5480.739)

Patten CS, Daniels D, Suzuki A, Fluharty SJ \& Yee DK 2007 Structural and signaling requirements of the human melanocortin 4 receptor for MAP kinase activation. Regulatory Peptides 142 111-122. (doi:10.1016/j.regpep.2007.02.005)

Perez DM \& Karnik SS 2005 Multiple signaling states of G-protein-coupled receptors. Pharmacological Reviews 57 147-161. (doi:10.1124/pr.57.2.2)

Pogozheva ID, Chai BX, Lomize AL, Fong TM, Weinberg DH, Nargund RP, Mulholland MW, Gantz I \& Mosberg HI 2005 Interactions of human melanocortin 4 receptor with nonpeptide and peptide agonists. Biochemistry 44 11329-11341. (doi:10.1021/ bi0501840)

Rasmussen SGF, Jensen AD, Liapakis G, Ghanouni P, Javitch JA \& Gether U 1999 Mutation of a highly conserved aspartic acid in the $\beta_{2}$-adrenergic receptor: constitutive activation, structural instability, and conformational rearrangement of transmembrane segment 6 . Molecular Pharmacology 56 175-184.

Rasmussen SGF, Choi HJ, Rosenbaum DM, Kobilka TS, Thian FS, Edwards PC, Burghammer M, Ratnala VRP, Sanishvili R, Fischetti RF et al. 2007 Crystal structure of the human $\beta_{2}$-adrenergic G protein-coupled receptor. Nature 450 383-387. (doi:10.1038/ nature06325)

Rasmussen SGF, Choi HJ, Fung JJ, Pardon E, Casarosa P, Chae PS, Devree BT, Rosenbaum DM, Thian FS, Kobilka TS et al. 2011 Structure of a nanobody-stabilized active state of the $\beta_{2}$ adrenoceptor. Nature 469 175-180. (doi:10.1038/nature09648)

Rosenbaum DM, Cherezov V, Hanson MA, Rasmussen SGF, Thian FS, Kobilka TS, Choi HJ, Yao XJ, Weis WI, Stevens RC et al. 2007 GPCR engineering yields high-resolution structural insights into $\beta_{2}$-adrenergic receptor function. Science 318 1266-1273. (doi:10.1126/science.1150609)

Rosenbaum DM, Zhang C, Lyons JA, Holl R, Aragao D, Arlow DH, Rasmussen SGF, Choi HJ, Devree BT, Sunahara RK et al. 2011 Structure and function of an irreversible agonist- $\beta_{2}$ adrenoceptor complex. Nature 469 236-240. (doi:10.1038/nature09665)

Roth CB, Hanson MA \& Stevens RC 2008 Stabilization of the human $\beta_{2}$-adrenergic receptor TM4-TM3-TM5 helix interface by mutagenesis of Glu122(3.41), a critical residue in GPCR structure. Journal of Molecular Biology 376 1305-1319. (doi:10.1016/j.jmb.2007. 12.028)

Sawyer TK, Sanfilippo PJ, Hruby VJ, Engel MH, Heward CB \& Burnett JB 1980 4-Norleucine, 7-D-phenylalanine- $\alpha$-melanocytestimulating hormone: a highly potent $\alpha$-melanotropin with ultralong biological activity. PNAS 77 5754-5758. (doi:10.1073/pnas.77. 10.5754)

Sheikh SP, Zvyaga TA, Lichtarge O, Sakmar TP \& Bourne HR 1996 Rhodopsin activation blocked by metal-ion-binding sites linking transmembrane helices C and F. Nature 383 347-350. (doi:10.1038/ 383347a0)

Shenoy SK, Drake MT, Nelson CD, Houtz DA, Xiao K, Madabushi S, Reiter E, Premont RT, Lichtarge O \& Lefkowitz RJ 2006 ß-Arrestindependent, $\mathrm{G}$ protein-independent ERK1/2 activation by the $\beta_{2}$ adrenergic receptor. Journal of Biological Chemistry 281 1261-1273. (doi:10.1074/jbc.M506576200)

Srinivasan S, Lubrano-Berthelier C, Govaerts C, Picard F, Santiago P, Conklin BR \& Vaisse C 2004 Constitutive activity of the melanocortin- 4 receptor is maintained by its $\mathrm{N}$-terminal domain and plays a role in energy homeostasis in humans. Journal of Clinical Investigation 114 1158-1164. (doi:10.1172/JCI200421927)

Sutton GM, Duos B, Patterson LM \& Berthoud HR 2005 Melanocortinergic modulation of cholecystokinin-induced suppression of feeding through extracellular signal-regulated kinase signaling in rat solitary nucleus. Endocrinology 146 3739-3747. (doi:10.1210/en. 2005-0562) 
Tan K, Pogozheva ID, Yeo GSH, Hadaschik D, Keogh JM, Haskell-Leuvano C, O’Rahilly S, Mosberg HI \& Farooqi IS 2009 Functional characterization and structural modeling of obesity associated mutations in the melanocortin 4 receptor. Endocrinology 150 114-125. (doi:10.1210/en.2008-0721)

Tansky MF, Pothoulakis C \& Leeman SE 2007 Functional consequences of alteration of N-linked glycosylation sites on the neurokinin 1 receptor. PNAS 104 10691-10696. (doi:10.1073/pnas. 0703394104)

Tao YX 2005 Molecular mechanisms of the neural melanocortin receptor dysfunction in severe early onset obesity. Molecular and Cellular Endocrinology 239 1-14. (doi:10.1016/j.mce.2005.04.012)

Tao YX 2006 Inactivating mutations of $\mathrm{G}$ protein-coupled receptors and diseases: structure-function insights and therapeutic implications. Pharmacology and Therapeutics 111 949-973. (doi:10.1016/ j.pharmthera.2006.02.008)

Tao YX 2008 Constitutive activation of G protein-coupled receptors and diseases: insights into mechanisms of activation and therapeutics. Pharmacology and Therapeutics 120 129-148. (doi:10.1016/ j.pharmthera.2008.07.005)

Tao YX 2009 Mutations in melanocortin-4 receptor and human obesity. Progress in Molecular Biology and Translational Science 88 173-204. (doi:10.1016/S1877-1173(09)8806-x)

Tao YX 2010 The melanocortin-4 receptor: physiology, pharmacology, and pathophysiology. Endocrine Reviews 31 506-543. (doi:10.1210/ er.2009-0037)

Tao YX \& Segaloff DL 2003 Functional characterization of melanocortin-4 receptor mutations associated with childhood obesity. Endocrinology 144 4544-4551. (doi:10.1210/en.2003-0524)

Tao YX \& Segaloff DL 2004 Functional characterization of melanocortin-3 receptor variants identify a loss-of-function mutation involving an amino acid critical for $\mathrm{G}$ protein-coupled receptor activation. Journal of Clinical Endocrinology and Metabolism 89 3936-3942. (doi:10.1210/jc.2004-0367)

Tao YX \& Segaloff DL 2005 Functional analyses of melanocortin-4 receptor mutations identified from patients with binge eating disorder and nonobese or obese subjects. Journal of Clinical Endocrinology and Metabolism 90 5632-5638. (doi:10.1210/jc.20050519)

Tao YX, Abell AN, Liu XB, Nakamura K \& Segaloff DL 2000 Constitutive activation of $\mathrm{G}$ protein-coupled receptors as a result of selective substitution of a conserved leucine residue in transmembrane helix III. Molecular Endocrinology 14 1272-1282. (doi:10.1210/me.14.8.1272)

Tao YX, Huang H, Wang ZQ, Yang F, Williams JN \& Nikiforovich GV 2010 Constitutive activity of neural melanocortin receptors. Methods in Enzymology 484 267-279. (doi:10.1016/B978-0-12-3812988.00014-9)

Valli-Jaakola K, Lipsanen-Nyman M, Oksanen L, Hollenberg AN, Kontula K, Bjorbaek C \& Schalin-Jantti C 2004 Identification and characterization of melanocortin-4 receptor gene mutations in morbidly obese Finnish children and adults. Journal of Clinical Endocrinology and Metabolism 89 940-945. (doi:10.1210/jc.2003031182)

Vongs A, Lynn NM \& Rosenblum CI 2004 Activation of MAP kinase by MC4-R through PI3 kinase. Regulatory Peptides 120 113-118. (doi:10. 1016/j.regpep.2004.02.018)

Wang ZQ \& Tao YX 2011 Functional studies on twenty novel naturally occurring melanocortin-4 receptor mutations. Biochimica et Biophysica Acta 1812 1190-1199. (doi:10.1016/j.bbadis.2011.06.008)
Wang SX, Fan ZC \& Tao YX 2008 Functions of acidic transmembrane residues in human melanocortin-3 receptor binding and activation. Biochemical Pharmacology 76 520-530. (doi:10.1016/j.bcp.2008. 05.026)

Wei H, Ahn S, Shenoy SK, Karnik SS, Hunyady L, Luttrell LM \& Lefkowitz RJ 2003 Independent $\beta$-arrestin 2 and G proteinmediated pathways for angiotensin II activation of extracellular signal-regulated kinases 1 and 2. PNAS 100 10782-10787. (doi:10.1073/pnas.1834556100)

Whalen EJ, Rajagopal S \& Lefkowitz RJ 2011 Therapeutic potential of $\beta$-arrestin- and $\mathrm{G}$ protein-biased agonists. Trends in Molecular Medicine 17 126-139. (doi:10.1016/j.molmed.2010.11.004)

Xiang Z, Litherland SA, Sorensen NB, Proneth B, Wood MS, Shaw AM, Millard WJ \& Haskell-Luevano C 2006 Pharmacological characterization of 40 human melanocortin-4 receptor polymorphisms with the endogenous proopiomelanocortin-derived agonists and the agouti-related protein (AGRP) antagonist. Biochemistry 45 7277-7288. (doi:10.1021/bi0600300)

Xiang Z, Proneth B, Dirain ML, Litherland SA \& Haskell-Luevano C 2010 Pharmacological characterization of 30 human melanocortin4 receptor polymorphisms with the endogenous proopiomelanocortin-derived agonists, synthetic agonists, and the endogenous agouti-related protein antagonist. Biochemistry 49 4583-4600. (doi:10.1021/bi100068u)

Yamano Y, Kamon R, Yoshimizu T, Toda Y, Oshida Y, Chaki S, Yoshioka M \& Morishima I 2004 The role of the DRY motif of human MC4R for receptor activation. Bioscience, Biotechnology, and Biochemistry 68 1369-1371. (doi:10.1271/bbb.68.1369)

Yang F \& Tao YX 2012 Functional characterization of nine novel naturally occurring human melanocortin-3 receptor mutations. Biochimica et Biophysica Acta 1822 1752-1761. (doi:10.1016/j.bbadis. 2012.07.017)

Yang Y, Fong TM, Dickinson CJ, Mao C, Li JY, Tota MR, Mosley R, Van der Ploeg LHT \& Gantz I 2000 Molecular determinants of ligand binding to the human melanocortin-4 receptor. Biochemistry 39 14900-14911. (doi:10.1021/bi001684q)

Yang Y, Chen M, Lai Y, Gantz I, Georgeson KE \& Harmon CM 2002 Molecular determinants of human melanocortin-4 receptor responsible for antagonist SHU9119 selective activity. Journal of Biological Chemistry 277 20328-20335. (doi:10.1074/jbc. M201343200)

Yang CZ, Asthagiri AR, Iyer RR, Lu J, Xu DS, Ksendzovsky A, Brady RO, Zhuang ZP \& Lonser RR 2011 Missense mutations in the NF2 gene result in the quantitative loss of merlin protein and minimally affect protein intrinsic function. PNAS 108 4980-4985. (doi:10.1073/ pnas.1102198108)

Zhai P, Yamamoto M, Galeotti J, Liu J, Masurekar M, Thaisz J, Irie K, Holle E, Yu X, Kupershmidt S et al. 2005 Cardiac-specific overexpression of AT1 receptor mutant lacking G alpha q/G alpha i coupling causes hypertrophy and bradycardia in transgenic mice. Journal of Clinical Investigation 115 3045-3056. (doi:10.1172/ JCI25330)

Zhang ML, Guan RB \& Segaloff DL 2012 Revisiting and questioning functional rescue between dimerized LH receptor mutants. Molecular Endocrinology 26 655-668. (doi:10.1210/me.2011-1285)

Received in final form 18 September 2012 Accepted 26 September 2012 Made available online as an Accepted Preprint 26 September 2012 